\title{
Epigenetic Mechanisms Involved in Cisplatin-Induced Nephrotoxicity: An Update
}

\author{
Pía Loren ${ }^{1}$, Nicolás Saavedra ${ }^{1}{ }^{1}$, Kathleen Saavedra ${ }^{1}$, Tomás Zambrano ${ }^{2}$, Patricia Moriel ${ }^{3}$ \\ and Luis A. Salazar $1, *$ (D) \\ 1 Center of Molecular Biology and Pharmacogenetics, Scientific and Technological Bioresource Nucleus, \\ Universidad de La Frontera, Temuco 4811230, Chile; pia.loren@ufrontera.cl (P.L.); \\ nicolas.saavedra@ufrontera.cl (N.S.); kathleen.saavedra@ufrontera.cl (K.S.) \\ 2 Department of Medical Technology, Faculty of Medicine, Universidad de Chile, Santiago 8380453, Chile; \\ tomas.zambrano@uchile.cl \\ 3 Faculty of Pharmaceutical Sciences, University of Campinas, Campinas 13083970, SP, Brazil; \\ patricia.moriel@fcf.unicamp.br \\ * Correspondence: luis.salazar@ufrontera.cl; Tel.: +56-452-596-724
}

check for updates

Citation: Loren, P.; Saavedra, N.; Saavedra, K.; Zambrano, T.; Moriel, P.; Salazar, L.A. Epigenetic Mechanisms Involved in Cisplatin-Induced Nephrotoxicity: An Update. Pharmaceuticals 2021, 14, 491. https:// doi.org/10.3390/ph14060491

Academic Editor: Marcin Ratajewski

Received: 1 May 2021

Accepted: 20 May 2021

Published: 21 May 2021

Publisher's Note: MDPI stays neutral with regard to jurisdictional claims in published maps and institutional affiliations.

Copyright: (c) 2021 by the authors. Licensee MDPI, Basel, Switzerland. This article is an open access article distributed under the terms and conditions of the Creative Commons Attribution (CC BY) license (https:// creativecommons.org/licenses/by/ $4.0 /)$.

\begin{abstract}
Cisplatin is an antineoplastic drug used for the treatment of many solid tumors. Among its various side effects, nephrotoxicity is the most detrimental. In recent years, epigenetic regulation has emerged as a modulatory mechanism of cisplatin-induced nephrotoxicity, involving non-coding RNAs, DNA methylation and histone modifications. These epigenetic marks alter different signaling pathways leading to damage and cell death. In this review, we describe how different epigenetic modifications alter different pathways leading to cell death by apoptosis, autophagy, necroptosis, among others. The study of epigenetic regulation is still under development, and much research remains to fully determine the epigenetic mechanisms underlying cell death, which will allow leading new strategies for the diagnosis and therapy of this disease.
\end{abstract}

Keywords: epigenetics; non-coding RNA; DNA methylation; histone modification; nephrotoxicity

\section{Introduction}

Globally, cancer is the second leading cause of death. In 2018, 18.1 million people worldwide had cancer, and 9.6 million died from this disease [1]. Cisplatin [cisdiamminedichloroplatinum (II), CDDP] is a well-known chemotherapeutic drug used for the treatment of numerous human cancer in solid organs, including head and neck [2], testis [3], small cells [4] and non-small cells [5] lung cancer, ovarian [6], cervical [7] and bladder [8]. Regarding the treatment of cancer cells, CDDP is potentially accompanied by some side effects such as ototoxicity, gastrotoxicity, neurotoxicity, myelosuppression, and allergic reactions [9]. Still, the main limiting side effect of CDDP use is nephrotoxicity [10]. Nephrotoxicity is defined as the rapid deterioration in kidney function due to the toxic effect of drugs, medications, and/or chemicals [11]. Cisplatin-induced-nephrotoxicity can occur in several ways, but the most severe and common is acute kidney injury, whose incidence after a single dose of CDDP fluctuates between 20-30\% in patients who receive an initial dose of $50-100 \mathrm{mg} / \mathrm{m}^{2}$ [9]. Cisplatin is concentrated and reabsorbed by tubular renal cells (5 times more than in the blood), which triggers a rapid decrease in renal function [12], resulting in morphological changes and altered signaling pathways, such as vacuolation, mitochondrial dysfunction, cell cycle arrest and apoptosis [13,14]. The diagnosis of kidney damage is carried out using standard biomarkers, such as serum creatinine ( $\mathrm{sCr}$ ) and blood urea nitrogen (BUN). However, their sensitivity and specificity are very low, and values are altered when significant kidney damage already exists [15].

In recent years, several studies showed that epigenetic processes are involved in cisplatin-induced nephrotoxicity. Wu and Morris [16] defined epigenetic as the "study of 
the changes in gene expression, which occur in organisms with differentiated cells, and the mitotic inheritance of given patterns of gene expression". These modifications regulate gene expression without changing the primary DNA sequence, triggering activation of transcription or gene silencing [17]. The main epigenetic mechanisms are represented by DNA methylation, histone modifications, and non-coding RNA. In general, epigenetic modifications are stable and heritable during cell divisions; however, they are potentially reversible and can be influenced by environmental factors. This review discusses recent findings in the epigenetics landscape of cisplatin-induced nephrotoxicity, focusing on the three mechanisms mentioned above.

\section{Induction Mechanism Cisplatin-Induced Nephrotoxicity}

Despite its therapeutic efficacy, the use of CDDP is limited due to the manifestation of side effects in normal tissues, mainly nephrotoxicity, whose incidence fluctuates between $20-30 \%$ in patients undergoing CDDP chemotherapy [9].

Cisplatin exerts its cytotoxic consequences by reacting with DNA, which ultimately culminates in irreversible apoptosis. Once CDDP goes through the cytosol, the low concentration of chloride present triggers the hydrolysis of the $\mathrm{Pt}-\mathrm{Cl}$ bonds. One of the $\mathrm{Cl}$ ligands is replaced by $\mathrm{H}_{2} \mathrm{O}$ to form the first positively charged CDDP derivative [18]. The subsequent hydrolysis results in the replacement of the next $\mathrm{Cl}$ ligand, leading to the formation of the second CDDP derivative [18]. Cisplatin hydrolyzed complexes bind to negatively charged DNA bases, inducing DNA damage by forming different types of adducts, resulting in the arrest of the cell cycle. Cisplatin interacts primarily with the N7 sites of purine residues in DNA to form inter-strand DNA crosslinks and intra-strand crosslinks at $5^{\prime}$-GG-3' sites of DNA bases. This results in defective DNA strands, causing the arrest of DNA synthesis and replication [19]. The main molecular sensor of DNA damage produced by CDPP is ATR (ataxia telangiectasia and Rad3-related), which is recruited to the site of damage and is co-localized with $\mathrm{H} 2 \mathrm{AX}$, forming nuclear foci. This is continued by the recruitment and activation of protein kinases, such as Chk1 and Chk2, which phosphorylate p53 [20], activating the signaling cascade that leads to cell death by apoptosis [21-26] or necrosis [27-29]. Although this way of DNA damage occurs in all cells, especially those that divide rapidly, such as tumor cells, this is considered the main mechanism mediating CDDP antitumor activity. CDDP cytotoxicity is not limited to cancer cells. In normal cells may lead to dangerous adverse effects such as ototoxicity, gastrotoxicity, myelosuppression, and allergic reactions. However, the major negative side effect of CDDP corresponds to nephrotoxicity [10]. After a single dose of CDDP (50-100 $\left.\mathrm{mg} / \mathrm{m}^{2}\right)$, approximately $30 \%$ of patients develop this pathology [9]. The nephrotoxic effect is produced by CDDP accumulation in the kidney, mainly in the S3 segment of the proximal tubules [30]. One of the reasons for its accumulation may be determined by the high density of negatively charged mitochondria in the proximal tubular cells, which attracts positively charged CDDP hydrolyzed complexes [31]. Once CDDP enters the cell, it can induce various mechanisms resulting in cell damage. The intrinsic pathway is the main apoptotic pathway during CDDP-induced nephrotoxicity. Cisplatin decreases anti-apoptotic proteins such as Bcl-2, Bcl-XL, and Mcl-1 [32,33]. This triggers external membrane permeabilization of the mitochondria, releasing apoptotic factors, such as cytochrome $c$ [34]. Once cytochrome $c$ is released, recruitment and activation of caspase-9 occurs, therefore activating caspase-3, initiating the process of caspase-dependent apoptosis [35]. Cisplatin treatment also activates p53 [36-39], which phosphorylation results in the activation of several molecules, such as p53-up-regulated modulator of apoptosis (PUMA- $\alpha$ ) and P53-induced protein with a death domain (PIDD) [21]. PIDD activates caspase-2, releasing apoptosis-inducing factor (AIF) from the mitochondria, resulting in caspase-independent activation [19]. On the other hand, PUMA- $\alpha$ translocates into mitochondria and interacts with BCL-XL, while BAX and BAK finally produce the release of cytochrome $c$, leading to caspase-dependent apoptosis [32,33]. Additionally, caspase-6 and -7 induction are produced during CDDP treatment [40]. Cisplatin also activates three 
major MAPKs: extracellular signal-regulated kinase (ERK), p38, and c-JUN N-terminal kinase (JNK) [35,41]. This induces oxidative stress, activating TNF- $\alpha$ and the consequent inflammatory response during CDDP-induced nephrotoxicity [42]. The augmented expression of ERK1/ 2 by CDDP treatment also activates NF- $\kappa \beta$ and $p 53$ signaling [43]. TNF- $\alpha$ increases tumor necrosis factors 1 and 2, TNFR1 and TNFR2, triggering the extrinsic apoptosis pathway through the activation of caspase-8, which will eventually lead to caspase-3 activation [9]. Cisplatin also regulates p21; its up-regulation protects from nephrotoxic damage [21]. Oxidative stress is a key factor contributing to nephrotoxicity since CDDP can react with glutathione, decreasing non-enzymatic (GSH and NADPH) and enzymatic (SOD, CAT, GPx, among others) antioxidant defense mechanisms [44]. Cisplatin also affects the mitochondrial respiratory complexes, leading to the inhibition of complexes I to IV of the respiratory chain and decreasing intracellular ATP levels [45]. In addition, CDDP also reduces the number of mitochondria in normal renal cells [43]. Finally, CDDP causes the activation of an adaptative program in the endoplasmic reticulum (ER) known as unfolded protein response (UPR), which inositol-requiring enzyme-1 (IRE1), double-stranded RNA-activated protein kinase-like ER kinase (PERK), and activating transcription factor-6 (ATF6) are dissociated from ER chaperone GRP78, activating signal transduction to inhibit protein translation [46]. Therefore, cisplatin-induced nephrotoxicity is a multifactorial and complex process involving multiple signaling pathways that in turn, may also be regulated by epigenetic mechanisms.

\section{DNA Methylation Role in Cisplatin-Induced Renal Dysfunction}

DNA methylation is an epigenetic modification involving the covalent addition of a methyl group to carbon 5 of a cytosine at $\mathrm{CpG}$ dinucleotides through the action of DNA methyltransferase enzymes (DNMTs) [47], which include DNMT1, DNMT2, DNMT3A, DNMT3B, and DNMT3L, contributing to hypermethylated (high methylation levels) or hypomethylated (low methylation levels) states of genes or genomic regions containing CpG residues [48]. In mammals, 70-80\% of CpG dinucleotides are methylated, whereas $\mathrm{CpG}$ islands in promoter regions of genes are demethylated, allowing transcription to proceed [49]. Therefore, the main function of DNA methylation is the regulation of transcription. Thus, hypomethylation in the promoter region correlates with gene activation by increased access for transcription factors, whereas hypermethylation in the promoter region results in loss of gene expression. Studies associating different DNA methylation patterns with CDDP-induced nephrotoxicity are scarce. Reports show that treatment of tubular cells with 5-aza-2'-deoxycytidine (5-AZA), a DNA methylation inhibitor, increases CDDP-induced apoptosis [50,51]. In addition, IRF8, a pro-apoptotic factor, is hypomethylated and induced after CDDP treatment, contributing to renal tubular cell apoptosis (Figure 1) [50]. In conjunction with 5-AZA, cisplatin decreases the expression of DNMT1, a maintenance DNMT, attenuating CDDP-induced nephrotoxicity [52]. It is recognized that OCT2, a transporter involved in organic cation transport, can transport CDDP to proximal tubules [53]. Based on this, studies show that methylation of the promoter region of OCT2 dramatically reduces the transcriptional activity of this transporter [54], which may contribute to increased toxicity. 


\section{Normal}
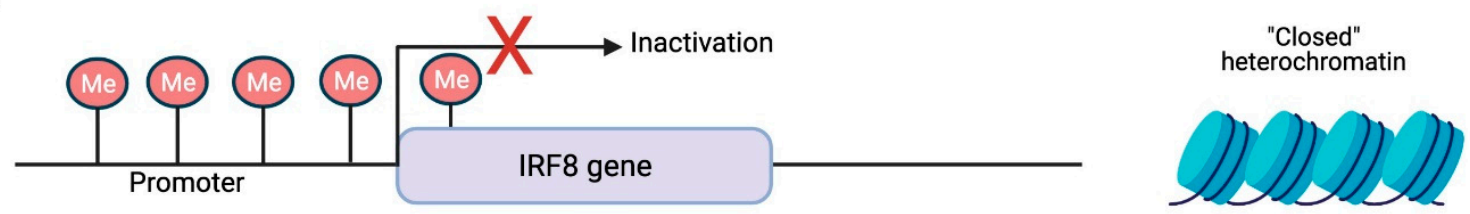

\section{Cisplatin-induced neprotoxicity}
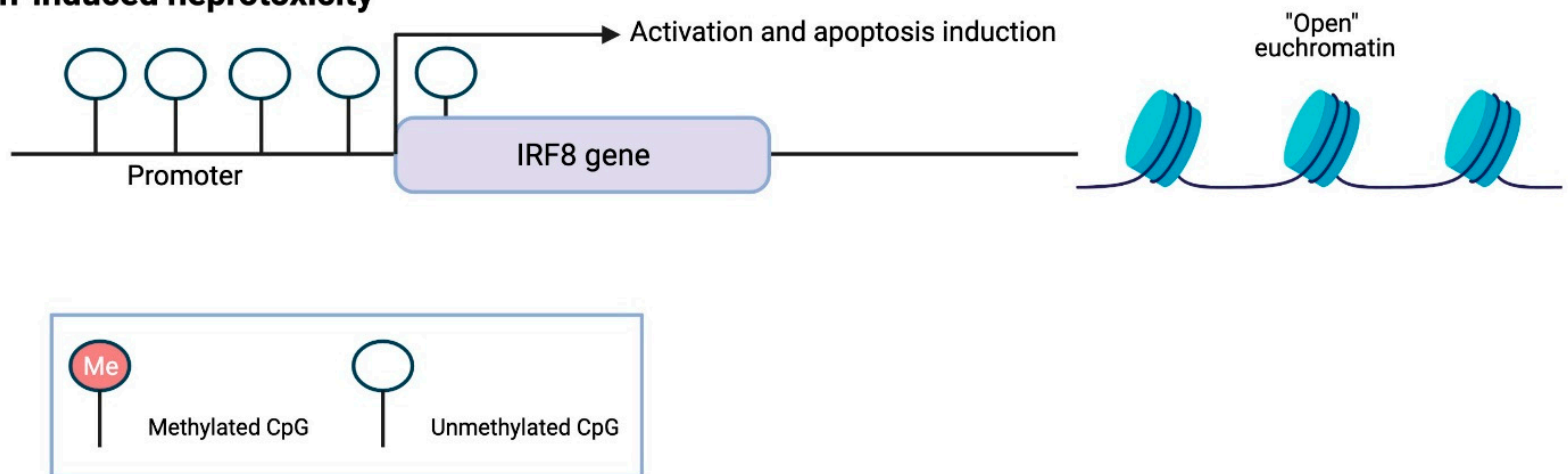

Figure 1. Demethylation of IRF8 gene promoter during cisplatin-induced nephrotoxicity, contributing to renal tubular cell apoptosis. Created with BioRender.com accessed on 21 May 2021.

\section{Cisplatin Nephrotoxicity and Histone Modifications}

The dynamic changes in chromatin structure, which allow its decondensation and remodeling, are processes necessary for gene transcription, DNA repair, and replication, carried out by post-translational modifications in the different histones [55]. Histones are the basic structural proteins of nucleosomes, which bind to double-helical DNA, forming the DNA-histone complex [47]. There are several types of histones, such as linker histones ( $\mathrm{H} 1$ and $\mathrm{H} 5)$ and core histones (H2A, H2B, H3, and $\mathrm{H} 4)$, whose function is associated with DNA packaging [49], where CDDP can easily react with $\mathrm{H} 1$ at methionine and glutamate residues, forming tertiary complexes that prevent DNA repair and increase sensitivity to CDDP [56]. Histone modifications occur predominantly at the N-terminal end, changing chromatin structure, positively or negatively affecting gene expression [49]. There are at least 8 histone modifications, but the most studied include histone acetylation and methylation, mostly in lysine and arginine residues.

Histone methylation involves the addition of a methyl group to a basic amino acid (lysine, arginine, and rarely in histidine) of core histones by a group of enzymes called histone methyltransferases (HMTs) [49]. Generally, methylation at H3 lysine 4 (H3K4), H3K36, and $\mathrm{H} 3 \mathrm{~K} 79$ activate gene transcription, whereas methylation at $\mathrm{H} 3 \mathrm{~K} 9, \mathrm{H} 3 \mathrm{~K} 27$, and $\mathrm{H} 4 \mathrm{~K} 20$ is associated with transcriptional repression [47]. CDDP treatment increases H3K27 trimethylation, leading to increased caspase 3 and decreased cell viability (Figure 2) [35]. Additionally, inhibition of enhancer of zeste homolog 2 (EZH2) -a histone methyltransferasewith 3-deazaneplanocin A (DZNep) in rat proximal tubular cells aggravates apoptosis by decreasing mTOR complexes [57].

On the other hand, histone acetylation involves adding an acetyl group to the lysine residue of core histones by a group of enzymes called histone acetyltransferases (HATs) [47]. This promotes open chromatin because a negative charge is added to the positively charged lysines, reducing the strong DNA-histone interaction, and thus, gene expression is activated [58]. One member of HATs is p300. This HAT can directly bind to transcription factors, such as p53 or NF-kB, and regulate their activities by acetylation $[59,60]$. Cisplatin induces p300 activation, acetylating lysines 18, 27, and 9 on H3, triggering functional and histological injury, increasing oxidative stress, inflammation, and apoptosis (Figure 2) [61]. One strategy 
to decrease CDDP-induced damage has been the inhibition of $\mathrm{p} 300$ by garcinol, attenuating the oxidative stress, inflammation, and apoptosis, by reducing the acetylation of the p65 subunit of NF- $\mathrm{KB}$ [61].

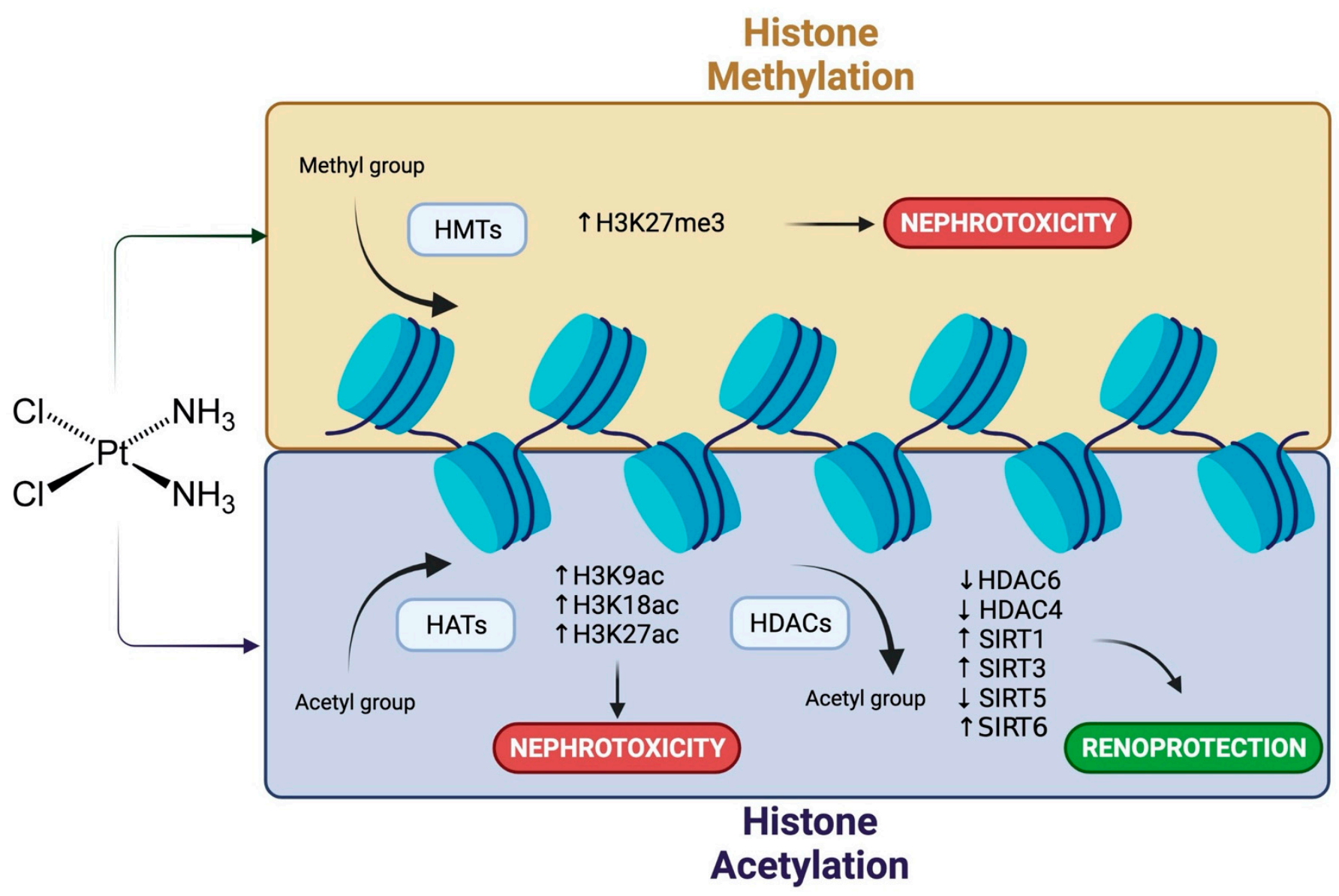

Figure 2. Proposed role of histone modifications in the regulation involved in cisplatin-induced nephrotoxicity. Created with BioRender.com accessed on 21 May 2021.

Acetylation is a reversible process catalyzed by enzymes called histone deacetylases (HDACs) [49]. HDACs are subdivided into four types: class I (HDAC1, 2, 3, and 8), class IIa (HDAC4, 5, 7, and 9), class IIb (HDAC6 and 10), class III (SIRT1-7), and class IV (HDAC11) [58]. One of the strategies to decrease CDDP-induced nephrotoxicity has been the use of HDACs class II inhibitors, as their overexpression is associated with increased apoptosis [62,63]. Studies have reported that the level of acetylated histone H3 is modified after CDDP treatment, but CDDP does not alter the abundance of histone H4 [64]. However, controversial results have been reported concerning acetylation of histone $\mathrm{H} 3$ with CDDP treatment. On the one hand, CDDP reduces levels of histone $\mathrm{H} 3$ acetylation in the injured kidney tissue $[46,65]$; however, another study demonstrated an increase in histone $\mathrm{H} 3$ acetylation after CDDP treatment in human renal cortical epithelial (HRCE) cells [66]. Although HDACs inhibitors do not prevent the DNA adducts formation and the initial damage response, they can interfere with the subsequent signaling [67]. Inhibition of HDAC6 by N-hydroxy-4-(2-methoxy-5-(methyl(2-methylquinazolin4-yl)amino)phenoxy)butanamide (23BB) reduces apoptosis and ER stress in the kidney of cisplatin-injured mice [46]. Additionally, HDAC6 inhibition by trichostatin A (TSA) reduces the renal pathological damage caused by CDDP treatment [65]. Finally, reduction of HDAC4 and HDAC5 with LMK-235 blocks the caspase-3 cleavage in HRCE cells [66]. The use of TSA, valproate (VPA) or suberoylanilide hydroxamic acid (SAHA) can confer kidney protection during CDDP treatment by H3K27 acetylation and IL-9 down- 
regulation [62], increase of BMP-7 [63], AMWAP [68,69] and PSTPIP2 [70]; increased CREB phosphorylation [71], reduction of caspase-3 activation [71] or by autophagy stimulation [72]. Even more, it has been demonstrated that SAHA inhibits and TSA delays phosphorylation, acetylation, and activation of p53 in rat proximal tubular cells [67]. On the other hand, overexpression of HDAC class III decreases CDDP-induced damage. Pharmacological overexpression of SIRT1 ameliorates the increased acetylation of p65 of NF- $\mathrm{KB}$ [73] and p53 [74] during cisplatin treatment, which decreases apoptosis, oxidative stress, and inflammation [64,75]. However, SIRT2 up-regulation increases phosphorylation of p38 and JNK, inducing apoptosis and renal damage in renal tissue [76]. In the same way, SIRT6 overexpression attenuates cisplatin-induced damage by repressing the expression of ERK1/2, thus inhibiting NF- $\mathrm{kB}$ and p53 signaling [43]. Finally, SIRT3 activation protects kidney tubular cells against oxidative stress by PARP1 inhibition [77], and its deficiency augments CDDP nephrotoxicity by increasing apoptosis and inflammatory response (Figure 2) [78]. However, silencing SIRT5 expression significantly improves kidney function and decreases tissue damage in mice submitted to CDDP damage [79].

\section{Involvement of Non-Coding RNAs in Cisplatin Nephrotoxicity}

Less than $2 \%$ of the human genome is transcribed into RNA to be translated into proteins. The remaining $98 \%$ is transcribed into a class of RNA that is not translated into proteins but plays a critical role in epigenetics. These molecules are called non-coding RNAs (ncRNAs) [47]. They regulate gene expression under physiological and pathological conditions, acting at various stages in protein synthesis at both transcriptional and posttranscriptional levels [80]. Non-coding RNAs are further divided into two main groups, small ncRNAs (shorter than $200 \mathrm{bp}$ ) and long ncRNA (lncRNAs; longer than $200 \mathrm{bp}$ ).

Out of small ncRNAs, microRNAs (miRs) have been by far the most extensively studied. They are a class of short-chain, linear, approximately 21-25 nucleotides long that negatively regulate gene targets at the post-transcriptional level by perfect complementarity of their "seed" region to 3'-UTR of its target mRNA, inducing their degradation. If there is a mismatch or imperfect complementarity, it results in translational repression [49]. The latest release of the miRbase database (v22) contains 2654 human mature miRs sequences [81], ratifying their importance on gene expression regulation.

Evidence shows that miRs mediate CDDP-induced nephrotoxicity in renal tubular cells through modulation of several molecules involved in a wide array of human (Table 1) and rodents (Table 2) signaling pathways, activating mechanisms such as DNA damage response, oxidative stress, autophagy, necroptosis, cell cycle arrest, apoptosis and inflammatory response (Figure 3). Cisplatin induces apoptosis in renal tubular cells [21-26], resulting in p53 activation. However, the epigenetic mechanism regulating cellular death is not well defined. Bhatt et al. demonstrated that induction of miR-34a in vitro during CDDP treatment in BLUMPT cells and in vivo during CDDP-induced nephrotoxicity in C57BL/ 6 mice were generated by p53. Still, this induction was abrogated in p53-deficient mice [21]. However, other studies showed that CDDP treatment down-regulates miR122 expression, causing FOXO3 acetylation and activation [36]; simultaneously, miR-34a expression is induced, causing SIRT1 repression $[36,37]$ together with triggering p53 activation [36]. FOXO3 activation also increases BNIP3L expression, a process that is mediated by miR-30c repression [22]. SIRT1 repression is also preceded by miR-449 up-regulation [32]. Upon CDDP-induced damage and consequent p53 activation, BAX is translocated into the mitochondria causing BCL-2 down-regulation, a process mediated by miR-181a [33], miR-449 [32], miR-21-5p and miR-200c [82]; and miR-107 [83]. CDDP treatment has also shown JNK induction [84], which promotes the apoptotic process. The decrease in mitochondrial membrane potential as a consequence of the increased BAX/BCL-2 ratio leads to the release of cytochrome $c$ into the cytosol, binding to other molecules to form the apoptosome and initiating the caspase activation cascade, which is modulated by miRs such as miR-26a [25], -30c [22], -34a [21], -375 [85] and -709 [23]. 


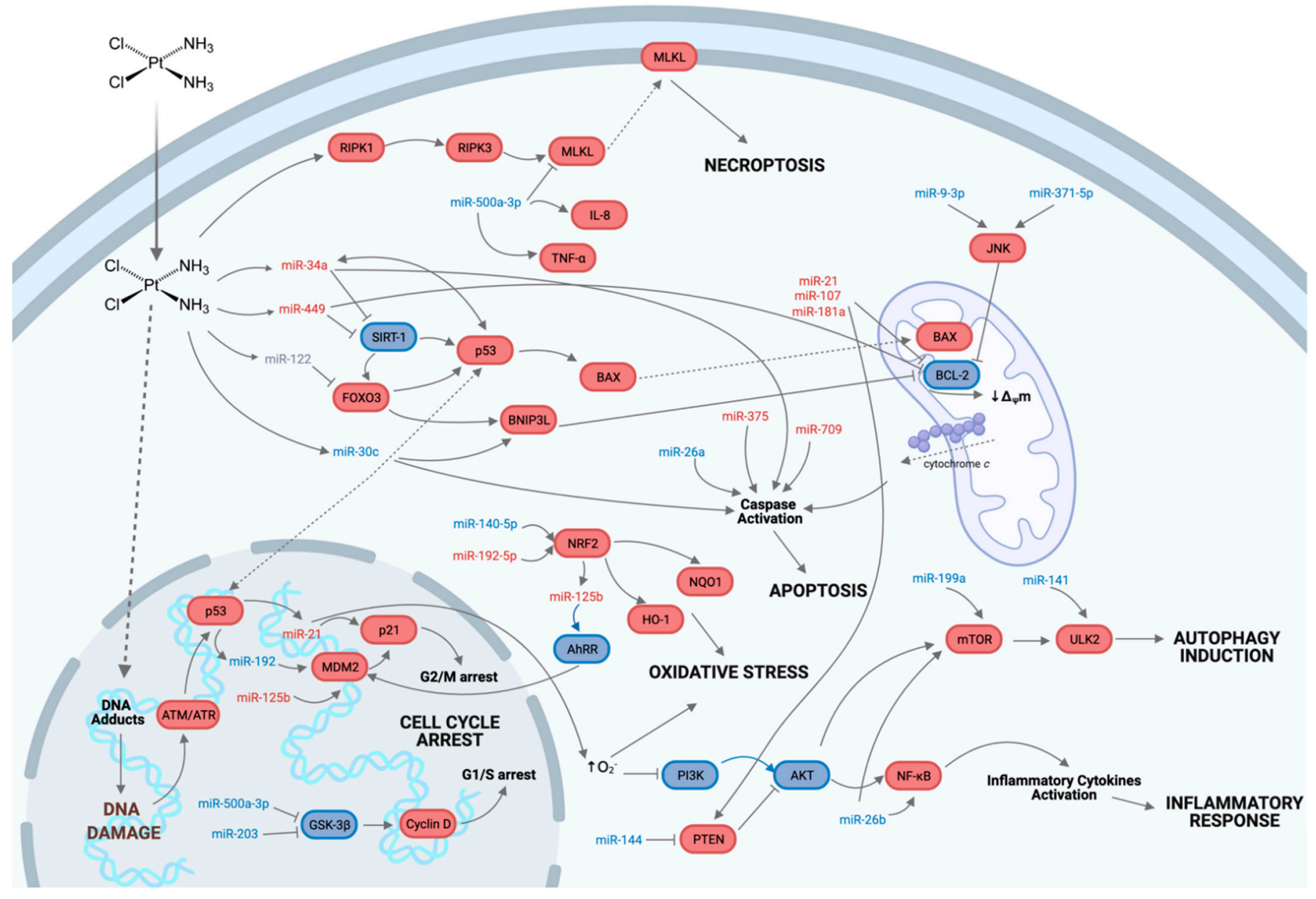

Figure 3. Proposed model of miRs function in the activation of different signaling pathways during cisplatin-induced nephrotoxicity in rodent and human tubular cells. Block arrows indicate inhibitory effect; single arrows indicate stimulatory effect. The blue color indicates gene expression down-regulation, while the red color indicates gene expression up-regulation. Created with BioRender.com accessed on 21 May 2021.

Although autophagy is generally activated under conditions of nutrient deprivation, it has also been implicated in physiological (development, differentiation) and pathological (neurodegenerative diseases, stress, infection, cancer) processes [86]. Based on this, it has been proven that CDDP also modulates the autophagy process in renal tubular cells $[87,88]$, although the epigenetic mechanisms underlying its occurrence have been poorly studied. However, it is known that CDDP modulates MAPK/ERK1/2 signaling pathway through miR-146b up-regulation [89]. Enhanced mir-146b levels directly impact the expression of mTOR, an autophagy initiation regulatory kinase, which is in turn mediated by miR199a up-regulation [38] and miR-26b down-regulation [90]. This allows the interaction of Atg13, FIPP200, and ULK1/2 [91], the last one being regulated by miR-141 repression [92]. The Atg13/FIPP200/ULK composite interacts with the PI3K class III complex, composed of several molecules, including Beclin-1, which recruit several ATG proteins, allowing the phagophore formation [91], and thus, starting the autophagy process.

Cisplatin also modulates cellular oxidative stress by regulating NRF2 [93], a transcription factor that regulates the expression of genes encoding antioxidant, anti-inflammatory, and detoxifying proteins [94]. Under normal conditions, NRF2 is located in the cytoplasm, negatively controlled by KEAP1; whereas, under oxidative stress conditions, KEAP1 releases NRF2, which can be translocated to the nucleus and, in this way, binds to antioxidant response elements (ARE), resulting in the transcription of antioxidant genes [95]. Some miRs have been shown to modulate KEAP1/NRF2 interaction, such as miR-192- 
$5 p$ [24] and miR-140-5p [93]. In addition to this, CDDP also alters the redox state, by decreasing the antioxidant activity of GSH, GSH-Px, and SOD [37].

Necroptosis is a programmed form of necrotic cell death considered passive cell death through regulated cell signaling pathways [96]. RIPK1, RIPK3, and MLKL are the main molecules involved in the necroptosis process. Necroptosis is triggered when TNFR1 is activated by TNF- $\alpha$, resulting in complex I formation. Subsequently, RIPK1, TRADD, and FADD are recruited. Once RIPK1 is activated, its interaction with RIPK3 occurs, forming complex IIb/necrosome, which mediates the phosphorylation of MLKL, whose translocation to the plasma membrane promotes necroptosis by disrupting plasma membrane integrity [97]. Some studies in renal tubular cells have demonstrated the involvement of miR-500a-3p in RIPK1, RIPK3, and MLKL regulation when these cells are treated with CDDP $[98,99]$. On the other hand, RIPK1 ubiquitination results in NF- $\mathrm{KB}$ activation, mediating the survival and production of multiple inflammatory cytokines, which are also regulated by several miRs when these cells are exposed to CDDP. Thus, IL-6 is mediated by miR-494 [15] and miR-34a [37]; IL-8 by miR-500a-3p [99]; and finally, IL-1 $\beta$ by miR-155 [100] and miR-34a [37].

The functional and pathological roles of lncRNAs also have been implicated in CDDPinduced nephrotoxicity. The lncRNA XLOC_032768 can attenuate CDDP-induced apoptosis through TNF- $\alpha$ up-regulation [101]. Similarly, PRNCR1 lncRNA also attenuates CDDPinduced damage in HK-2 cells through up-regulation of EZH1 expression [102]. However, some lncRNAs have been implicated in nephrotoxic damage. Thus, during CDDP-induced damage, lncRNA LRNA9884 increases NF- $\mathrm{kB}$-mediated inflammatory cytokines, especially MIF [103]. Likewise, IncRNA GAS5 can increase CDDP-induced apoptosis of HK-2 cells by modulating miR-205-5p [104].

Circular RNAs (circRNAs) are single-stranded, covalently locked transcripts produced from a precursor mRNA [105]. These circRNAs can act as sponges for miRs, resulting in increased expression [49]. In this way, circ-0114427 attracts miR-494 and interacts with it, increasing ATF3 expression and reducing inflammatory cytokines, thus exerting a nephroprotective role against CDDP damage [15]. 
Table 1. In vitro and in vivo evidence of microRNAs involved in cisplatin-induced nephrotoxicity in humans.

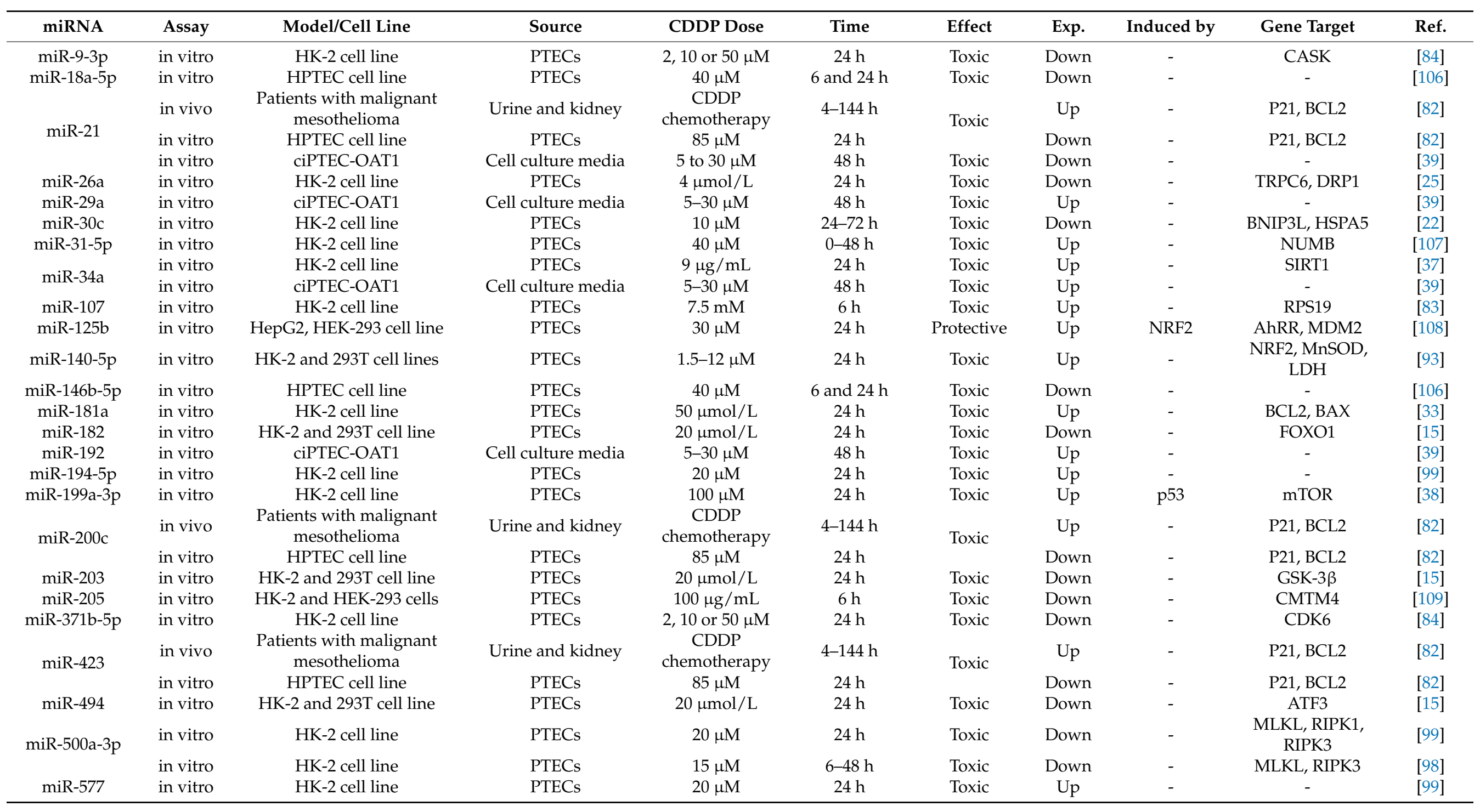


Table 1. Cont.

\begin{tabular}{|c|c|c|c|c|c|c|c|c|c|c|}
\hline miRNA & Assay & Model/Cell Line & Source & CDDP Dose & Time & Effect & Exp. & Induced by & Gene Target & Ref. \\
\hline miR-3168 & in vivo & $\begin{array}{l}\text { Patients with primary } \\
\text { squamous cell carcinoma of } \\
\text { the head and neck }\end{array}$ & Blood & $\begin{array}{c}\text { CDDP } \\
\text { chemotherapy }\end{array}$ & - & Toxic & Up & - & PRKAB2, TOP2A & [110] \\
\hline $\operatorname{miR}-4718$ & in vivo & $\begin{array}{c}\text { Patients with primary } \\
\text { squamous cell carcinoma of } \\
\text { the head and neck }\end{array}$ & Blood & $\begin{array}{c}\text { CDDP } \\
\text { chemotherapy }\end{array}$ & - & Toxic & Down & - & PRKAB2, ERCC1 & [110] \\
\hline miR-6125 & in vivo & $\begin{array}{c}\text { Patients with primary } \\
\text { squamous cell carcinoma of } \\
\text { the head and neck }\end{array}$ & Blood & $\begin{array}{c}\text { CDDP } \\
\text { chemotherapy }\end{array}$ & - & Toxic & Up & - & ERCC1 & [110] \\
\hline
\end{tabular}

Table 2. In vitro and in vivo evidence of microRNAs involved in cisplatin-induced nephrotoxicity in rodents.

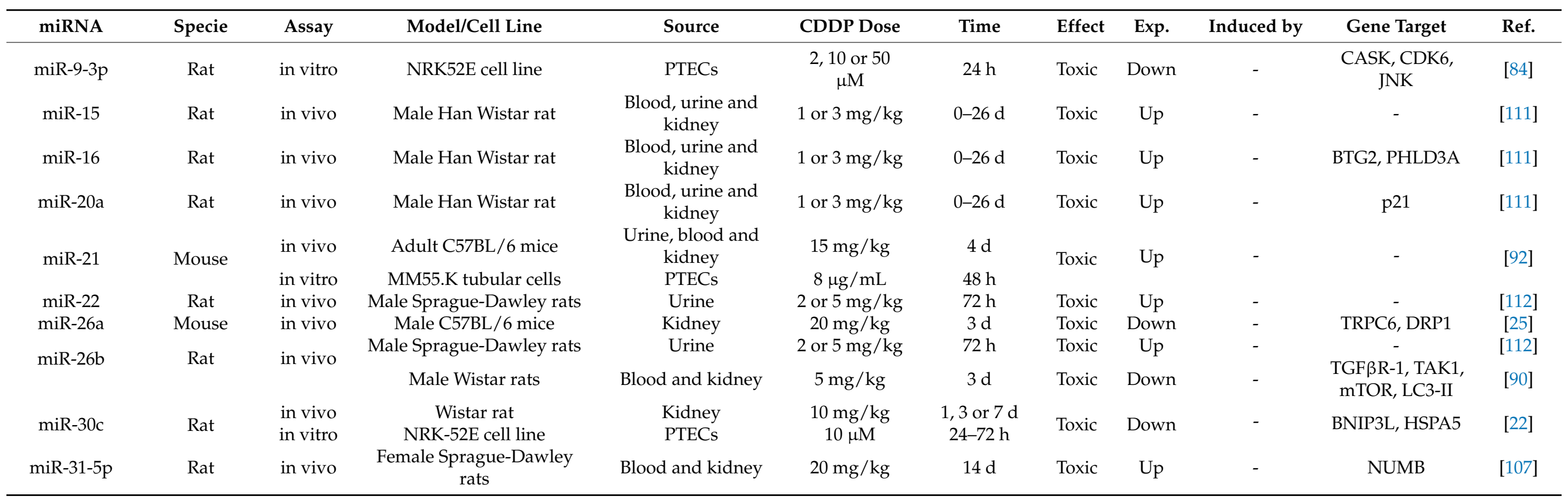


Table 2. Cont.

\begin{tabular}{|c|c|c|c|c|c|c|c|c|c|c|c|}
\hline miRNA & Specie & Assay & Model/Cell Line & Source & CDDP Dose & Time & Effect & Exp. & Induced by & Gene Target & Ref. \\
\hline \multirow{5}{*}{$\operatorname{miR}-34 a$} & Mouse & in vitro & BUMPT-306 cell line & PTECs & $40 \mu \mathrm{mol} / \mathrm{L}$ & $0-20 \mathrm{~h}$ & Toxic & Up & - & p53 & [21] \\
\hline & Mouse & in vivo & $\begin{array}{c}\text { Wild-type and } \\
\text { p53-deficientC57BL/6 mice }\end{array}$ & Blood and kidney & $30 \mathrm{mg} / \mathrm{kg}$ & $0-3 d$ & $10 \times 1 C$ & P & & pou & {$[21]$} \\
\hline & Rat & in vitro & NRK-52E cell line & PTECs & $9 \mu \mathrm{g} / \mathrm{mL}$ & $24 \mathrm{~h}$ & \multirow{2}{*}{ Toxic } & \multirow{2}{*}{ Up } & - & SIRT1 & [37] \\
\hline & RatMouse & in vivo & $\begin{array}{l}\text { Male Wistar ratsMale } \\
\text { C57BL-6J mice }\end{array}$ & Blood and kidney & $7 \mathrm{mg} / \mathrm{kg} 25 \mathrm{mg} / \mathrm{kg}$ & $12 \mathrm{~d}$ & & & - & - & [37] \\
\hline & Rat & in vivo & Male Wistar rats & Blood and kidney & $5 \mathrm{mg} / \mathrm{kg}$ & $3 d$ & Toxic & Down & - & $\begin{array}{l}\text { TGF } \beta \text { R-1, TAK1, } \\
\text { mTOR, LC3-II }\end{array}$ & {$[90]$} \\
\hline miR-34c & Rat & in vivo & Male Sprague-Dawley rats & Kidney and plasma & 2 or $5 \mathrm{mg} / \mathrm{kg}$ & $72 \mathrm{~h}$ & Toxic & Up & - & - & [112] \\
\hline $\operatorname{miR}-34 c-5 p$ & Rat & in vivo & Male Hannover Wistar rats & Kidney and urine & $2.5 \mathrm{mg} / \mathrm{kg}$ & $0-27 \mathrm{~d}$ & Toxic & Down & - & - & [113] \\
\hline \multirow[t]{2}{*}{ miR-92a } & \multirow[t]{2}{*}{ Mouse } & in vivo & Adult C57BL/6 mice & $\begin{array}{l}\text { Urine, blood and } \\
\text { kidney }\end{array}$ & & $4 \mathrm{~d}$ & \multirow[t]{2}{*}{ Toxic } & \multirow[t]{2}{*}{ Down } & - & \multirow[t]{2}{*}{-} & \multirow[t]{2}{*}{ [92] } \\
\hline & & in vitro & MM55.K tubular cells & PTECs & $8 \mu \mathrm{g} / \mathrm{mL}$ & $48 \mathrm{~h}$ & & & - & & \\
\hline miR-92b & Rat & in vivo & Male Sprague-Dawley rats & Plasma & 2 or $5 \mathrm{mg} / \mathrm{kg}$ & $72 \mathrm{~h}$ & Toxic & Up & - & - & [112] \\
\hline miR-93-5p & Rat & in vivo & Male Sprague-Dawley rats & Kidney and urine & $\begin{array}{c}1,3 \text { or } \\
6 \mathrm{mg} / \mathrm{kg}\end{array}$ & $1-7 \mathrm{~d}$ & Toxic & Up & - & - & [114] \\
\hline miR-107 & Rat & in vivo & Male Sprague-Dawley rats & Kidney and blood & $6 \mathrm{mg} / \mathrm{kg}$ & $3 d$ & Toxic & Up & - & RPS19 & [83] \\
\hline miR-122 & Mouse & in vivo & Male C57BL/ 6 mice & Kidney & $15 \mathrm{mg} / \mathrm{kg}$ & $3 d$ & Toxic & Down & - & $\begin{array}{l}\text { FOXO3, p53, } \\
\text { PHLDA3 }\end{array}$ & [36] \\
\hline miR-122-5p & Rat & in vivo & Male Sprague-Dawley rats & Blood and kidney & $6 \mathrm{mg} / \mathrm{kg}$ & $1-5 d$ & Toxic & Down & - & - & [115] \\
\hline $\operatorname{miR}-125 b$ & Mouse & in vivo & $\begin{array}{c}\text { Male C57BL / } 6 \text { mice and } \\
\text { Nrf2 KO }\end{array}$ & Blood and kidney & $15 \mathrm{mg} / \mathrm{kg}$ & $3 d$ & Protect & ve Up & NRF2 & AhRR, MDM2 & [108] \\
\hline miR-128 & Rat & in vivo & Male Sprague-Dawley rats & Plasma & 2 or $5 \mathrm{mg} / \mathrm{kg}$ & $72 \mathrm{~h}$ & Toxic & Up & - & - & [112] \\
\hline miR-130b & Rat & in vivo & Male Sprague-Dawley rats & Plasma & 2 or $5 \mathrm{mg} / \mathrm{kg}$ & $72 \mathrm{~h}$ & Toxic & Up & - & - & [112] \\
\hline $\operatorname{miR}-134$ & Rat & in vivo & Male Sprague-Dawley rats & Plasma & 2 or $5 \mathrm{mg} / \mathrm{kg}$ & $72 \mathrm{~h}$ & Toxic & $\mathrm{Up}$ & - & - & [112] \\
\hline $\operatorname{miR}-138$ & Mouse & in vivo & $\begin{array}{l}\text { Female Diversity Outbred } \\
\text { mice }\end{array}$ & Urine and kidney & $5 \mathrm{mg} / \mathrm{kg}$ & $3 d$ & Toxic & Up & - & - & [26] \\
\hline miR-140 & Rat & in vivo & Male Sprague-Dawley rats & Urine & 2 or $5 \mathrm{mg} / \mathrm{kg}$ & $72 \mathrm{~h}$ & Toxic & Up & - & - & [112] \\
\hline \multirow[t]{2}{*}{ miR-140-5p } & \multirow[t]{2}{*}{ Mouse } & in vivo & Adult male mice & Blood and kidney & $20 \mathrm{mg} / \mathrm{kg}$ & $1-14 \mathrm{~d}$ & Toxic & Up & - & $\begin{array}{l}\text { NRF2, MnSOD, } \\
\text { LDH }\end{array}$ & [93] \\
\hline & & in vivo & Male C57BL/6J mice & Blood and kidney & $20 \mathrm{mg} / \mathrm{kg}$ & $19 \mathrm{~d}$ & Toxic & Down & - & NRF2, p53 & {$[24]$} \\
\hline
\end{tabular}


Table 2. Cont.

\begin{tabular}{|c|c|c|c|c|c|c|c|c|c|c|c|}
\hline miRNA & Specie & Assay & Model/Cell Line & Source & CDDP Dose & Time & Effect & Exp. & Induced by & Gene Target & Ref. \\
\hline miR-141 & Mouse & in vivo & Adult C57BL/6 mice & $\begin{array}{l}\text { Urine, blood and } \\
\text { kidney }\end{array}$ & $15 \mathrm{mg} / \mathrm{kg}$ & $4 \mathrm{~d}$ & Toxic & Down & - & ULK2 & [92] \\
\hline miR-143-3p & Rat & $\begin{array}{l}\text { in vitro } \\
\text { in vivo }\end{array}$ & $\begin{array}{c}\text { MM55.K tubular cells } \\
\text { Male Sprague-Dawley rats }\end{array}$ & $\begin{array}{c}\text { PTECs } \\
\text { Blood and kidney }\end{array}$ & $\begin{array}{l}8 \mu \mathrm{g} / \mathrm{mL} \\
6 \mathrm{mg} / \mathrm{kg}\end{array}$ & $\begin{array}{l}48 \mathrm{~h} \\
1-5 \mathrm{~d}\end{array}$ & Toxic & Down & - & - & [115] \\
\hline miR-144 & Mouse & in vivo & Male C57BL/6 mice & Blood and kidney & $20 \mathrm{mg} / \mathrm{kg}$ & $6 \mathrm{~h}$ & Toxic & Down & - & $\begin{array}{l}\text { PTEN, ATK, } \\
\text { GSk } 3 \beta\end{array}$ & [116] \\
\hline & Rat & in vivo & Male Sprague-Dawley rats & Kidney & 2 or $5 \mathrm{mg} / \mathrm{kg}$ & $72 \mathrm{~h}$ & Toxic & Down & - & - & [112] \\
\hline miR-146a & Mouse & in vivo & Male Balb/C mice & Blood and kidney & $10 \mathrm{mg} / \mathrm{kg}$ & $24 \mathrm{~h}$ & Toxic & Up & - & - & [117] \\
\hline & & in vivo & Male Sprague-Dawley rats & Kidney & 2 or $5 \mathrm{mg} / \mathrm{kg}$ & $72 \mathrm{~h}$ & Toxic & Up & - & - & [112] \\
\hline $\operatorname{miR}-151$ & Rat & in vivo & Male Sprague-Dawley rats & Plasma & 2 or $5 \mathrm{mg} / \mathrm{kg}$ & $72 \mathrm{~h}$ & Toxic & Up & - & - & [112] \\
\hline $\operatorname{miR}-155$ & Mouse & in vivo & $\begin{array}{c}\text { miR-155 } \\
\text { mice }\end{array}$ & Blood and kidney & $20 \mathrm{mg} / \mathrm{kg}$ & $72 \mathrm{~h}$ & Toxic & Down & - & $\begin{array}{l}\text { c-FOS, TNF- } \alpha, \\
\text { IL-1 } \beta\end{array}$ & [100] \\
\hline miR-181a & Mouse & in vivo & Male C57BL/6 mice & Blood and kidney & $20 \mathrm{mg} / \mathrm{kg}$ & $3 \mathrm{~d}$ & Toxic & Up & - & PTEN & [118] \\
\hline $\operatorname{miR}-181 b$ & Rat & in vivo & Male Sprague-Dawley rats & Plasma & 2 or $5 \mathrm{mg} / \mathrm{kg}$ & $72 \mathrm{~h}$ & Toxic & $\mathrm{Up}$ & - & - & [112] \\
\hline miR-182 & Mouse & in vivo & Male C57BL/ 6 mice & Blood and kidney & $30 \mathrm{mg} / \mathrm{kg}$ & $72 \mathrm{~h}$ & Toxic & Down & - & FOXO1 & [15] \\
\hline miR-191a & Rat & in vivo & Male Sprague-Dawley rats & Plasma & 2 or $5 \mathrm{mg} / \mathrm{kg}$ & $72 \mathrm{~h}$ & Toxic & Up & - & - & [112] \\
\hline miR-192 & Rat & in vivo & Male Han Wistar rat & $\begin{array}{l}\text { Blood, urine and } \\
\text { kidney }\end{array}$ & 1 or $3 \mathrm{mg} / \mathrm{kg}$ & $0-26 \mathrm{~d}$ & Toxic & Up & - & - & [111] \\
\hline miR-192-5p & Rat & in vivo & Male Sprague-Dawley rats & Kidney and urine & $\begin{array}{l}1,3 \text { or } \\
6 \mathrm{mg} / \mathrm{kg}\end{array}$ & $1-7 \mathrm{~d}$ & Toxic & Up & - & - & [114] \\
\hline & Mouse & in vivo & Male C57BL/6J mice & Kidney and blood & $20 \mathrm{mg} / \mathrm{kg}$ & $19 \mathrm{~d}$ & Toxic & Down & - & NRF2, p53 & [24] \\
\hline $\operatorname{miR}-193$ & Rat & in vivo & Male Han Wistar rat & $\begin{array}{l}\text { Blood, urine and } \\
\text { kidney }\end{array}$ & 1 or $3 \mathrm{mg} / \mathrm{kg}$ & $0-26 \mathrm{~d}$ & Toxic & Up & - & - & [111] \\
\hline miR-199a-3p & Mouse & in vivo & Male C57 / BL mice & Kidney & $20 \mathrm{mg} / \mathrm{kg}$ & $3 d$ & Toxic & Up & p53 & mTOR & [38] \\
\hline miR-203 & Mouse & in vivo & Male C57BL/ 6 mice & Blood and kidney & $30 \mathrm{mg} / \mathrm{kg}$ & $72 \mathrm{~h}$ & Toxic & Down & - & GSK-3 $\beta$ & [15] \\
\hline miR-208a & Mouse & $\begin{array}{l}\text { in vivo } \\
\text { in vitro }\end{array}$ & $\begin{array}{l}\text { Adult C57BL/ } 6 \text { mice } \\
\text { MM55.K tubular cells }\end{array}$ & $\begin{array}{l}\text { Urine, blood and } \\
\text { kidney } \\
\text { PTECs }\end{array}$ & $\begin{array}{l}15 \mathrm{mg} / \mathrm{kg} \\
8 \mu \mathrm{g} / \mathrm{mL}\end{array}$ & $\begin{array}{r}4 \mathrm{~d} \\
48 \mathrm{~h}\end{array}$ & Toxic & Down & - & - & [92] \\
\hline $\operatorname{miR}-210$ & Rat & in vivo & Male Han Wistar rat & $\begin{array}{l}\text { Blood, urine and } \\
\text { kidney }\end{array}$ & 1 or $3 \mathrm{mg} / \mathrm{kg}$ & $0-26 \mathrm{~d}$ & Toxic & Up & - & - & [111] \\
\hline
\end{tabular}


Table 2. Cont.

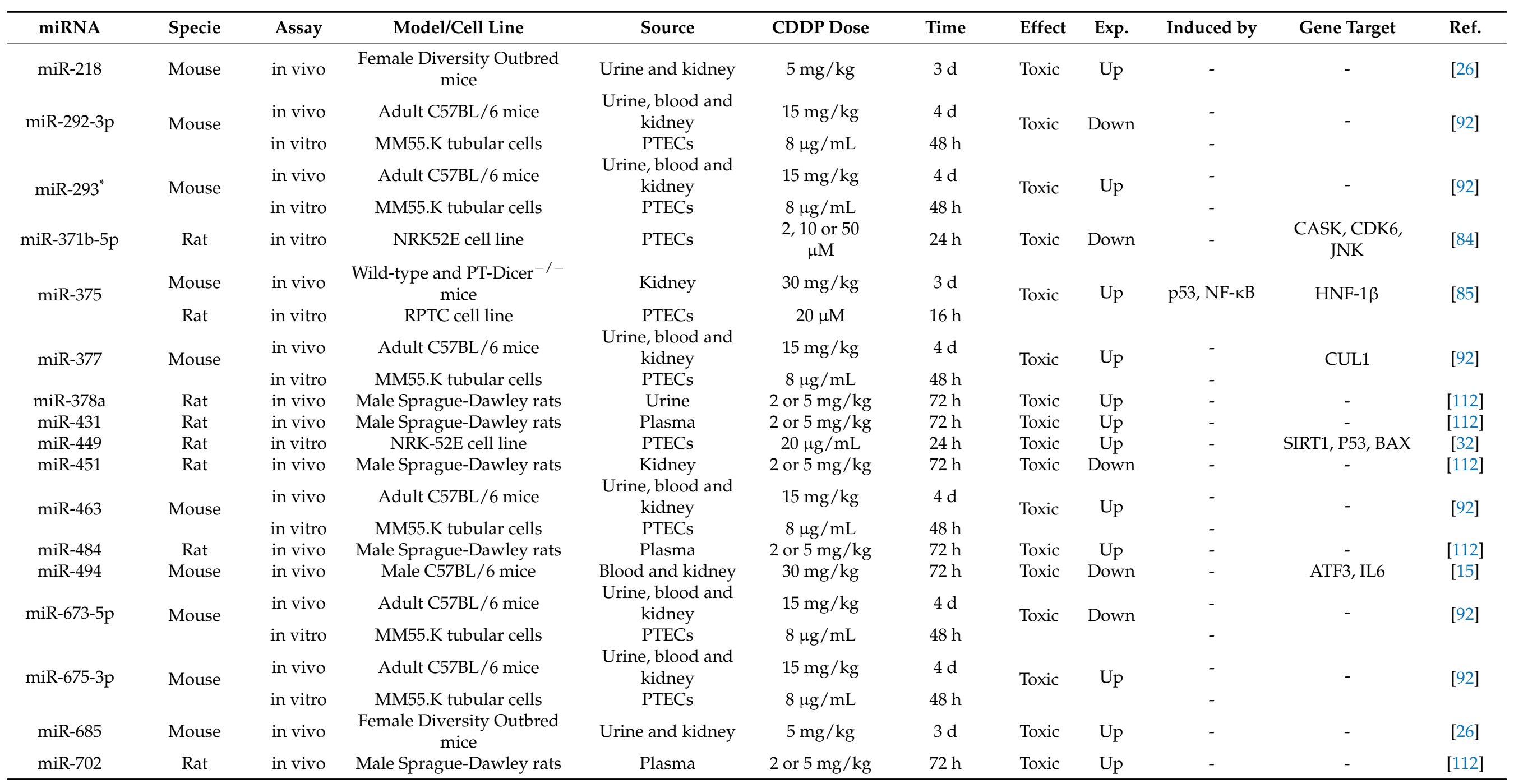


Table 2. Cont.

\begin{tabular}{|c|c|c|c|c|c|c|c|c|c|c|c|}
\hline miRNA & Specie & Assay & Model/Cell Line & Source & CDDP Dose & Time & Effect & Exp. & Induced by & Gene Target & Ref. \\
\hline miR-709 & Mouse & $\begin{array}{l}\text { in vivo } \\
\text { in vitro }\end{array}$ & $\begin{array}{l}\text { C57BL / } 6 \text { mice } \\
\text { mPTC cell line }\end{array}$ & $\begin{array}{l}\text { Blood and kidney } \\
\text { PTECs }\end{array}$ & $\begin{array}{c}20 \mathrm{mg} / \mathrm{kg} \\
1-20 \mu \mathrm{M}\end{array}$ & $\begin{array}{c}72 \mathrm{~h} \\
2-24 \mathrm{~h}\end{array}$ & Toxic & Up & - & TFAM & [23] \\
\hline $\operatorname{miR}-741$ & Mouse & $\begin{array}{l}\text { in vivo } \\
\text { in vitro }\end{array}$ & $\begin{array}{l}\text { Adult C57BL/ } 6 \text { mice } \\
\text { MM55.K tubular cells }\end{array}$ & $\begin{array}{l}\text { Urine, blood and } \\
\text { kidney } \\
\text { PTECs }\end{array}$ & $\begin{array}{l}15 \mathrm{mg} / \mathrm{kg} \\
8 \mu \mathrm{g} / \mathrm{mL}\end{array}$ & $\begin{array}{r}4 \mathrm{~d} \\
48 \mathrm{~h}\end{array}$ & Toxic & $\mathrm{Up}$ & - & - & [92] \\
\hline miR-1190 & Mouse & $\begin{array}{l}\text { in vivo } \\
\text { in vitro }\end{array}$ & $\begin{array}{l}\text { Adult C57BL/6 mice } \\
\text { MM55.K tubular cells }\end{array}$ & $\begin{array}{l}\text { Urine, blood and } \\
\text { kidney } \\
\text { PTECs }\end{array}$ & $\begin{array}{l}15 \mathrm{mg} / \mathrm{kg} \\
8 \mu \mathrm{g} / \mathrm{mL}\end{array}$ & $\begin{array}{r}4 \mathrm{~d} \\
48 \mathrm{~h}\end{array}$ & Toxic & Down & - & - & [92] \\
\hline miR-let-7b & Rat & in vivo & Male Wistar rats & Blood and kidney & $5 \mathrm{mg} / \mathrm{kg}$ & $3 d$ & Toxic & Down & - & $\begin{array}{l}\text { TGF } \beta R-1, \text { TAK1, } \\
\text { mTOR, LC3-II }\end{array}$ & [90] \\
\hline $\begin{array}{l}\text { miR-let-7e } \\
\text { miR-let-7g }\end{array}$ & $\begin{array}{l}\text { Rat } \\
\text { Rat }\end{array}$ & $\begin{array}{l}\text { in vivo } \\
\text { in vivo }\end{array}$ & $\begin{array}{l}\text { Male Sprague-Dawley rats } \\
\text { Male Sprague-Dawley rats }\end{array}$ & $\begin{array}{l}\text { Plasma } \\
\text { Urine }\end{array}$ & $\begin{array}{l}2 \text { or } 5 \mathrm{mg} / \mathrm{kg} \\
2 \text { or } 5 \mathrm{mg} / \mathrm{kg}\end{array}$ & $\begin{array}{l}72 \mathrm{~h} \\
72 \mathrm{~h}\end{array}$ & $\begin{array}{l}\text { Toxic } \\
\text { Toxic }\end{array}$ & $\begin{array}{l}\mathrm{Up} \\
\mathrm{Up}\end{array}$ & - & - & $\begin{array}{l}{[112]} \\
{[112]}\end{array}$ \\
\hline $\begin{array}{l}\text { miR-let-7g- } \\
5 p\end{array}$ & Rat & in vivo & Male Sprague-Dawley rats & Kidney and urine & $\begin{array}{l}1,3 \text { or } \\
6 \mathrm{mg} / \mathrm{kg}\end{array}$ & $1-7 \mathrm{~d}$ & Toxic & $\mathrm{Up}$ & - & - & [114] \\
\hline
\end{tabular}

PTECs: Proximal Tubular Epithelial Cells. 


\section{Potential Challenges and Future Directions}

Epigenetics is an active research field concerning cisplatin-induced nephrotoxicity. So far, studies show that the mechanisms involved play a significant role in the pathogenesis of this condition. However, little is known about the interaction between different epigenetic marks. Nonetheless, crosstalk between epigenetic modifications does exist in this pathology. For example, during CDDP-induced nephrotoxicity, lncRNA LRNA9884 increases NF- $\mathrm{KB}$ expression [103]. On the other hand, miR-34 [21,36], miR-192-5p [24] and, miR-449 [32] activate p53. Both NF-kB and p53 up-regulate miR-375 [85], inducing apoptosis in renal proximal tubular cells. However, inhibiting p300 attenuates this adverse effect due to reduced acetylation of NF- $\kappa \mathrm{B}$ [61]. In the same way, overexpression of SIRT1 and SIRT6 inhibits p53 signaling, reducing cisplatin-induced damage [43,74]. Clearly, there are many gaps regarding epigenetic modulation in the pathogenesis of this condition, especially in the cross-talking for these mechanisms. Understanding the way that DNA methylation, histone modifications, and ncRNAs underlie this disease will provide us with the opportunity to discover new biomarkers for early diagnosis, as well as the establishment of novel therapies or treatments aiming to decrease the incidence of cisplatin-induced nephrotoxicity.

\section{Conclusions}

Nephrotoxicity is the most lethal side effect of cisplatin treatment. During the last few years, rapid progress has been made in understanding the contribution of epigenetic mechanisms underlying nephrotoxicity to be used as potential biomarkers for early diagnosis and/or to employ different therapeutic strategies. These studies demonstrate the complexity of the interactions of epigenetic modifications, which have provided a better understanding of the epigenetic regulation of CDDP-induced nephrotoxicity. Continued research in this area will provide new therapeutic targets and early, sensitive, and specific diagnostic biomarkers to detect CDDP-induced nephrotoxicity.

Author Contributions: Conceptualization, P.L. and L.A.S.; methodology, P.L.; software, P.L.; validation, P.L., K.S., N.S. and P.M.; formal analysis, P.L. and N.S.; investigation, P.L.; resources, L.A.S.; data curation, P.L.; writing-original draft preparation, P.L.; writing—review and editing, P.L., T.Z., P.M. and L.A.S.; visualization, L.A.S.; supervision, L.A.S.; project administration, P.M. and L.A.S.; funding acquisition, N.S., K.S., P.M. and L.A.S. All authors have read and agreed to the published version of the manuscript.

Funding: This research was funded by ANID-FAPESP (Grant Number 19/13250-1), FONDECYT (Grant Number 1171765) and Programa de Formación de Investigadores Postdoctorales, VRIP, Universidad de La Frontera, Temuco, Chile (Code VRIP 21001).

Institutional Review Board Statement: Not applicable.

Informed Consent Statement: Not applicable.

Data Availability Statement: No new data were created or analyzed in this study. Data sharing is not applicable to this article.

Conflicts of Interest: The authors declare no conflict of interest.

\section{References}

1. WHO. World Health Statistics 2020: Monitoring Health for the SDGs; World Health Organization: Geneva, Switzerland, 2020; Volume 21, pp. 1-9. [CrossRef]

2. Vermorken, J.B.; Remenar, E.; van Herpen, C.; Gorlia, T.; Mesia, R.; Degardin, M.; Stewart, J.S.; Jelic, S.; Betka, J.; Preiss, J.H.; et al. Cisplatin, fluorouracil, and docetaxel in unresectable head and neck cancer. N. Engl. J. Med. 2007, 357, 1695-1704. [CrossRef] [PubMed]

3. Motzer, R.J.; Sheinfeld, J.; Mazumdar, M.; Bajorin, D.F.; Bosl, G.J.; Herr, H.; Lyn, P.; Vlamis, V. Etoposide and cisplatin adjuvant therapy for patients with pathologic stage II germ cell tumors. J. Clin. Oncol. 1995, 13, 2700-2704. [CrossRef]

4. Li, D.; Zhang, Y.; Xie, Y.; Xiang, J.; Zhu, Y.; Yang, J. Enhanced tumor suppression by adenoviral PTEN gene therapy combined with cisplatin chemotherapy in small-cell lung cancer. Cancer Gene Ther. 2013, 20, 251-259. [CrossRef] [PubMed] 
5. Magali, L.; Pascal, F.; Serge, A.; Mathieu, B.; Ayoube, Z.; Claire, T.; Christiane, M. Better survival in impaired renal function patients with metastatic non-small cell lung cancer treated by cisplatin-pemetrexed. Eur. J. Clin. Pharmacol. 2020, 76, 1573-1580. [CrossRef]

6. $\quad$ Armstrong, D.K.; Bundy, B.; Wenzel, L.; Huang, H.Q.; Baergen, R.; Lele, S.; Copeland, L.J.; Walker, J.L.; Burger, R.A. Intraperitoneal cisplatin and paclitaxel in ovarian cancer. N. Engl. J. Med. 2006, 354, 34-43. [CrossRef] [PubMed]

7. Moore, K.N.; Herzog, T.J.; Lewin, S.; Giuntoli, R.L.; Armstrong, D.K.; Rocconi, R.P.; Spannuth, W.A.; Gold, M.A. A comparison of cisplatin/paclitaxel and carboplatin/paclitaxel in stage IVB, recurrent or persistent cervical cancer. Gynecol. Oncol. 2007, 105, 299-303. [CrossRef]

8. Coppin, C.M.; Gospodarowicz, M.K.; James, K.; Tannock, I.F.; Zee, B.; Carson, J.; Pater, J.; Sullivan, L.D. Improved local control of invasive bladder cancer by concurrent cisplatin and preoperative or definitive radiation. The National Cancer Institute of Canada Clinical Trials Group. J. Clin. Oncol. 1996, 14, 2901-2907. [CrossRef]

9. Miller, R.P.; Tadagavadi, R.K.; Ramesh, G.; Reeves, W.B. Mechanisms of Cisplatin nephrotoxicity. Toxins 2010, 2, 2490-2518. [CrossRef]

10. Arany, I.; Safirstein, R.L. Cisplatin nephrotoxicity. Semin. Nephrol. 2003, 23, 460-464. [CrossRef]

11. Al-Naimi, M.; Rasheed, H.; Hussien, N.; Al-Kuraishy, H.; Al-Gareeb, A. Nephrotoxicity: Role and significance of renal biomarkers in the early detection of acute renal injury. J. Adv. Pharm. Technol. Res. 2019, 10, 95-99. [CrossRef]

12. Griffin, B.R.; Faubel, S.; Edelstein, C.L. Biomarkers of drug-induced kidney toxicity. Ther. Drug Monit. 2019, 41, 213-226. [CrossRef]

13. Alfieri, A.B.; Cubeddu, L.X. Role of NK1 receptors on cisplatin-induced nephrotoxicity in the rat. Naunyn Schmiedebergs Arch. Pharmacol. 2000, 361, 334-338. [CrossRef]

14. Zhu, S.; Pabla, N.; Tang, C.; He, L.; Dong, Z. DNA damage response in cisplatin-induced nephrotoxicity. Arch. Toxicol. 2015, 89, 2197-2205. [CrossRef]

15. Cao, Y.; Mi, X.; Zhang, D.; Wang, Z.; Zuo, Y.; Tang, W. Transcriptome sequencing of circular RNA reveals a novel circular RNA-has_circ_0114427 in the regulation of inflammation in acute kidney injury. Clin. Sci. 2020, 134, 139-154. [CrossRef] [PubMed]

16. Wu, C.; Morris, J.R. Genes, genetics, and epigenetics: A correspondence. Science 2001, 293, 1103-1105. [CrossRef]

17. Calcagno, D.Q.; Gigek, C.O.; Chen, E.S.; Burbano, R.R.; Smith Mde, A. DNA and histone methylation in gastric carcinogenesis. World J. Gastroenterol. 2013, 19, 1182-1192. [CrossRef] [PubMed]

18. Lau, J.K.; Ensing, B. Hydrolysis of cisplatin-a first-principles metadynamics study. Phys. Chem. Chem. Phys. 2010, 12, 10348-10355. [CrossRef]

19. Galgamuwa, R. An Investigation Into The Prevention Of Cisplatin-Induced Nephrotoxicity By Dichloroacetate. Australian National University. Available online: https:/ / openresearch-repository.anu.edu.au/ (accessed on 1 May 2021).

20. Pabla, N.; Huang, S.; Mi, Q.S.; Daniel, R.; Dong, Z. ATR-Chk2 signaling in p53 activation and DNA damage response during cisplatin-induced apoptosis. J. Biol. Chem. 2008, 283, 6572-6583. [CrossRef]

21. Bhatt, K.; Zhou, L.; Mi, Q.S.; Huang, S.; She, J.X.; Dong, Z. MicroRNA-34a is induced via p53 during cisplatin nephrotoxicity and contributes to cell survival. Mol. Med. 2010, 16, 409-416. [CrossRef] [PubMed]

22. Du, B.; Dai, X.M.; Li, S.; Qi, G.L.; Cao, G.X.; Zhong, Y.; Yin, P.D.; Yang, X.S. MiR-30c regulates cisplatin-induced apoptosis of renal tubular epithelial cells by targeting Bnip3L and Hspa5. Cell Death Dis. 2017, 8, e2987. [CrossRef] [PubMed]

23. Guo, Y.; Ni, J.; Chen, S.; Bai, M.; Lin, J.; Ding, G.; Zhang, Y.; Sun, P.; Jia, Z.; Huang, S.; et al. MicroRNA-709 Mediates Acute Tubular Injury through Effects on Mitochondrial Function. J. Am. Soc. Nephrol. 2018, 29, 449-461. [CrossRef]

24. Zou, D.; Ganugula, R.; Arora, M.; Nabity, M.B.; Sheikh-Hamad, D.; Kumar, M. Oral delivery of nanoparticle urolithin A normalizes cellular stress and improves survival in mouse model of cisplatin-induced AKI. Am. J. Physiol. Renal Physiol. 2019, 317, F1255-F1264. [CrossRef]

25. Yang, Y.; Li, Z.L.; Wang, F.M.; Tang, R.N.; Tu, Y.; Liu, H. MicroRNA26a inhibits cisplatin-induced renal tubular epithelial cells apoptosis through suppressing the expression of transient receptor potential channel 6 mediated dynamin-related protein 1. Cell Biochem. Funct. 2020, 38, 384-391. [CrossRef]

26. Harrill, A.H.; Lin, H.; Tobacyk, J.; Seely, J.C. Mouse population-based evaluation of urinary protein and miRNA biomarker performance associated with cisplatin renal injury. Exp. Biol. Med. 2018, 243, 237-247. [CrossRef]

27. Liu, Z.; Li, Z.; Chen, Z.; Li, C.; Lei, L.; Wu, X.; Li, Y. Numb ameliorates necrosis and inflammation in acute kidney injury induced by cisplatin. Chem. Biol. Interact. 2020, 330, 109251. [CrossRef]

28. Ramesh, G.; Reeves, W.B. TNFR2-mediated apoptosis and necrosis in cisplatin-induced acute renal failure. Am. J. Physiol. Renal Physiol. 2003, 285, F610-F618. [CrossRef]

29. Landau, S.I.; Guo, X.; Velazquez, H.; Torres, R.; Olson, E.; Garcia-Milian, R.; Moeckel, G.W.; Desir, G.V.; Safirstein, R. Regulated necrosis and failed repair in cisplatin-induced chronic kidney disease. Kidney Int. 2019, 95, 797-814. [CrossRef] [PubMed]

30. Nosaka, K.; Nakada, J.; Endou, H. Cisplatin-induced alterations in renal structure, ammoniagenesis and gluconeogenesis of rats. Kidney Int. 1992, 41, 73-79. [CrossRef] [PubMed]

31. Qian, W.; Nishikawa, M.; Haque, A.M.; Hirose, M.; Mashimo, M.; Sato, E.; Inoue, M. Mitochondrial density determines the cellular sensitivity to cisplatin-induced cell death. Am. J. Physiol. Cell Physiol. 2005, 289, C1466-C1475. [CrossRef] [PubMed] 
32. Qin, W.; Xie, W.; Yang, X.; Xia, N.; Yang, K. Inhibiting microRNA-449 Attenuates Cisplatin-Induced Injury in NRK-52E Cells Possibly via Regulating the SIRT1/P53/BAX Pathway. Med. Sci. Monit. 2016, 22, 818-823. [CrossRef]

33. Zhu, H.Y.; Liu, M.Y.; Hong, Q.; Zhang, D.; Geng, W.J.; Xie, Y.S.; Chen, X.M. Role of microRNA-181a in the apoptosis of tubular epithelial cell induced by cisplatin. Chin. Med. J. 2012, 125, 523-526. [CrossRef]

34. McDonald, E.S.; Windebank, A.J. Cisplatin-induced apoptosis of DRG neurons involves bax redistribution and cytochrome c release but not fas receptor signaling. Neurobiol. Dis. 2002, 9, 220-233. [CrossRef] [PubMed]

35. Ni, J.; Hou, X.; Wang, X.; Shi, Y.; Xu, L.; Zheng, X.; Liu, N.; Qiu, A.; Zhuang, S. 3-deazaneplanocin A protects against cisplatininduced renal tubular cell apoptosis and acute kidney injury by restoration of E-cadherin expression. Cell Death Dis. 2019, 10, 355. [CrossRef] [PubMed]

36. Lee, C.G.; Kim, J.G.; Kim, H.J.; Kwon, H.K.; Cho, I.J.; Choi, D.W.; Lee, W.H.; Kim, W.D.; Hwang, S.J.; Choi, S.; et al. Discovery of an integrative network of microRNAs and transcriptomics changes for acute kidney injury. Kidney Int. 2014, 86, 943-953. [CrossRef] [PubMed]

37. Zhang, Y.; Tao, X.; Yin, L.; Xu, L.; Xu, Y.; Qi, Y.; Han, X.; Song, S.; Zhao, Y.; Lin, Y.; et al. Protective effects of dioscin against cisplatin-induced nephrotoxicity via the microRNA-34a/sirtuin 1 signalling pathway. Br. J. Pharmacol. 2017, 174, $2512-2527$. [CrossRef]

38. Yang, A.; Liu, F.; Guan, B.; Luo, Z.; Lin, J.; Fang, W.; Liu, L.; Zuo, W. p53 induces miR-199a-3p to suppress mechanistic target of rapamycin activation in cisplatin-induced acute kidney injury. J. Cell Biochem. 2019, 120, 17625-17634. [CrossRef] [PubMed]

39. Suter-Dick, L.; Mauch, L.; Ramp, D.; Caj, M.; Vormann, M.K.; Hutter, S.; Lanz, H.L.; Vriend, J.; Masereeuw, R.; Wilmer, M.J. Combining Extracellular miRNA Determination with Microfluidic 3D Cell Cultures for the Assessment of Nephrotoxicity: A Proof of Concept Study. AAPS J. 2018, 20, 86. [CrossRef]

40. Yang, C.; Kaushal, V.; Haun, R.S.; Seth, R.; Shah, S.V.; Kaushal, G.P. Transcriptional activation of caspase- 6 and -7 genes by cisplatin-induced p53 and its functional significance in cisplatin nephrotoxicity. Cell Death Differ. 2008, 15, 530-544. [CrossRef]

41. Sun, L.; Liu, J.; Yuan, Y.; Zhang, X.; Dong, Z. Protective effect of the BET protein inhibitor JQ1 in cisplatin-induced nephrotoxicity. Am. J. Physiol. Renal Physiol. 2018, 315, F469-F478. [CrossRef]

42. Sun, C.Y.; Nie, J.; Zheng, Z.L.; Zhao, J.; Wu, L.M.; Zhu, Y.; Su, Z.Q.; Zheng, G.J.; Feng, B. Renoprotective effect of scutellarin on cisplatin-induced renal injury in mice: Impact on inflammation, apoptosis, and autophagy. Biomed. Pharmacother. 2019, 112, 108647. [CrossRef]

43. Li, Z.; Xu, K.; Zhang, N.; Amador, G.; Wang, Y.; Zhao, S.; Li, L.; Qiu, Y.; Wang, Z. Overexpressed SIRT6 attenuates cisplatin-induced acute kidney injury by inhibiting ERK1/2 signaling. Kidney Int. 2018, 93, 881-892. [CrossRef]

44. Almaghrabi, O.A. Molecular and biochemical investigations on the effect of quercetin on oxidative stress induced by cisplatin in rat kidney. Saudi J. Biol. Sci. 2015, 22, 227-231. [CrossRef] [PubMed]

45. Kruidering, M.; Van de Water, B.; de Heer, E.; Mulder, G.J.; Nagelkerke, J.F. Cisplatin-induced nephrotoxicity in porcine proximal tubular cells: Mitochondrial dysfunction by inhibition of complexes I to IV of the respiratory chain. J. Pharmacol. Exp. Ther. 1997, 280, 638-649.

46. Hao, Y.; Guo, F.; Huang, Z.; Feng, Y.; Xia, Z.; Liu, J.; Li, L.; Huang, R.; Lin, L.; Ma, L.; et al. 2-Methylquinazoline derivative 23BB as a highly selective histone deacetylase 6 inhibitor alleviated cisplatin-induced acute kidney injury. Biosci. Rep. 2020, 40. [CrossRef]

47. Xiang, X.; Guo, C.; Tang, C.; Cai, J.; Dong, Z. Epigenetic Regulation in Kidney Toxicity: Insights From Cisplatin Nephrotoxicity. Semin. Nephrol. 2019, 39, 152-158. [CrossRef] [PubMed]

48. Saldanha, S.N.; Tollefsbol, T.O. Epigenetic Approaches to Cancer Therapy. In Epigenetics in Human Disease; Tollefsbol, T.O., Ed.; Academic Press: Cambridge, MA, USA, 2018; Volume 6, pp. 219-247.

49. Guo, C.; Dong, G.; Liang, X.; Dong, Z. Epigenetic regulation in AKI and kidney repair: Mechanisms and therapeutic implications. Nat. Rev. Nephrol. 2019, 15, 220-239. [CrossRef] [PubMed]

50. Guo, C.; Pei, L.; Xiao, X.; Wei, Q.; Chen, J.K.; Ding, H.F.; Huang, S.; Fan, G.; Shi, H.; Dong, Z. DNA methylation protects against cisplatin-induced kidney injury by regulating specific genes, including interferon regulatory factor 8 . Kidney Int. 2017, 92, 1194-1205. [CrossRef] [PubMed]

51. Scholpa, N.E.; Kolli, R.T.; Moore, M.; Arnold, R.D.; Glenn, T.C.; Cummings, B.S. Nephrotoxicity of epigenetic inhibitors used for the treatment of cancer. Chem. Biol. Interact. 2016, 258, 21-29. [CrossRef]

52. Tikoo, K.; Ali, I.Y.; Gupta, J.; Gupta, C. 5-Azacytidine prevents cisplatin induced nephrotoxicity and potentiates anticancer activity of cisplatin by involving inhibition of metallothionein, pAKT and DNMT1 expression in chemical induced cancer rats. Toxicol. Lett. 2009, 191, 158-166. [CrossRef]

53. Qian, C.Y.; Zheng, Y.; Wang, Y.; Chen, J.; Liu, J.Y.; Zhou, H.H.; Yin, J.Y.; Liu, Z.Q. Associations of genetic polymorphisms of the transporters organic cation transporter 2 (OCT2), multidrug and toxin extrusion 1 (MATE1), and ATP-binding cassette subfamily $\mathrm{C}$ member 2 (ABCC2) with platinum-based chemotherapy response and toxicity in non-small cell lung cancer patients. Chin. J. Cancer 2016, 35, 85. [CrossRef]

54. Aoki, M.; Terada, T.; Kajiwara, M.; Ogasawara, K.; Ikai, I.; Ogawa, O.; Katsura, T.; Inui, K. Kidney-specific expression of human organic cation transporter 2 (OCT2/SLC22A2) is regulated by DNA methylation. Am. J. Physiol. Renal Physiol. 2008, 295, F165-F170. [CrossRef] [PubMed]

55. Mercurio, C.; Plyte, S.; Minucci, S. Chapter 4-Alterations of Histone Modifications in Cancer. In Epigenetics in Human Disease; Translational Epigenetics; Elsevier Inc.: Amsterdam, The Netherlands, 2012; pp. 53-87. [CrossRef] 
56. Cheng, L.; Li, C.; Xi, Z.; Wei, K.; Yuan, S.; Arnesano, F.; Natile, G.; Liu, Y. Cisplatin reacts with histone H1 and the adduct forms a ternary complex with DNA. Metallomics 2019, 11, 556-564. [CrossRef] [PubMed]

57. Chen, S.Q.; Li, J.Q.; Wang, X.Q.; Lei, W.J.; Li, H.; Wan, J.; Hu, Z.; Zou, Y.W.; Wu, X.Y.; Niu, H.X. EZH2-inhibitor DZNep enhances apoptosis of renal tubular epithelial cells in presence and absence of cisplatin. Cell Div. 2020, 15, 8. [CrossRef] [PubMed]

58. Hosseini, A.; Minucci, S. Chapter 6-Alterations of Histone Modifications in Cancer. In Epigenetics in Human Disease; Tollefsbol, T.O., Ed.; Academic Press: Cambridge, MA, USA; Elsevier Inc.: Amsterdam, The Netherlands, 2018; Volume 6, pp. 141-217.

59. Gu, W.; Roeder, R.G. Activation of p53 sequence-specific DNA binding by acetylation of the p53 C-terminal domain. Cell 1997, 90, 595-606. [CrossRef]

60. Chen, L.F.; Mu, Y.; Greene, W.C. Acetylation of RelA at discrete sites regulates distinct nuclear functions of NF-kappaB. EMBO J. 2002, 21, 6539-6548. [CrossRef] [PubMed]

61. Kim, J.Y.; Jo, J.; Leem, J.; Park, K.K. Inhibition of p300 by Garcinol Protects against Cisplatin-Induced Acute Kidney Injury through Suppression of Oxidative Stress, Inflammation, and Tubular Cell Death in Mice. Antioxidants 2020, 9, 1271. [CrossRef]

62. Jiang, W.; Yuan, X.; Zhu, H.; He, C.; Ge, C.; Tang, Q.; Xu, C.; Hu, B.; Huang, C.; Ma, T. Inhibition of Histone H3K27 Acetylation Orchestrates Interleukin-9-Mediated and Plays an Anti-Inflammatory Role in Cisplatin-Induced Acute Kidney Injury. Front. Immunol. 2020, 11, 231. [CrossRef]

63. Ma, T.; Huang, C.; Xu, Q.; Yang, Y.; Liu, Y.; Meng, X.; Li, J.; Ye, M.; Liang, H. Suppression of BMP-7 by histone deacetylase 2 promoted apoptosis of renal tubular epithelial cells in acute kidney injury. Cell Death Dis. 2017, 8, e3139. [CrossRef] [PubMed]

64. Sakao, Y.; Kato, A.; Tsuji, T.; Yasuda, H.; Togawa, A.; Fujigaki, Y.; Kahyo, T.; Setou, M.; Hishida, A. Cisplatin induces Sirt1 in association with histone deacetylation and increased Werner syndrome protein in the kidney. Clin. Exp. Nephrol. 2011, 15, 363-372. [CrossRef]

65. Tang, J.; Shi, Y.; Liu, N.; Xu, L.; Zang, X.; Li, P.; Zhang, J.; Zheng, X.; Qiu, A.; Zhuang, S. Blockade of histone deacetylase 6 protects against cisplatin-induced acute kidney injury. Clin. Sci 2018, 132, 339-359. [CrossRef]

66. Mikami, D.; Kobayashi, M.; Uwada, J.; Yazawa, T.; Kamiyama, K.; Nishimori, K.; Nishikawa, Y.; Morikawa, Y.; Yokoi, S.; Takahashi, N.; et al. beta-Hydroxybutyrate, a ketone body, reduces the cytotoxic effect of cisplatin via activation of HDAC5 in human renal cortical epithelial cells. Life Sci. 2019, 222, 125-132. [CrossRef] [PubMed]

67. Dong, G.; Luo, J.; Kumar, V.; Dong, Z. Inhibitors of histone deacetylases suppress cisplatin-induced p53 activation and apoptosis in renal tubular cells. Am. J. Physiol. Renal Physiol. 2010, 298, F293-F300. [CrossRef] [PubMed]

68. Tang, J.; Zhuang, S. Upregulation of AMWAP: A novel mechanism for HDAC inhibitors to protect against cisplatin nephrotoxicity. Kidney Int. 2016, 89, 267-269. [CrossRef] [PubMed]

69. Ranganathan, P.; Hamad, R.; Mohamed, R.; Jayakumar, C.; Muthusamy, T.; Ramesh, G. Histone deacetylase-mediated silencing of AMWAP expression contributes to cisplatin nephrotoxicity. Kidney Int. 2016, 89, 317-326. [CrossRef]

70. Zhu, H.; Jiang, W.; Zhao, H.; He, C.; Tang, X.; Xu, S.; Xu, C.; Feng, R.; Li, J.; Ma, T.; et al. PSTPIP2 inhibits cisplatin-induced acute kidney injury by suppressing apoptosis of renal tubular epithelial cells. Cell Death Dis. 2020, 11, 1057. [CrossRef]

71. Arany, I.; Herbert, J.; Herbert, Z.; Safirstein, R.L. Restoration of CREB function ameliorates cisplatin cytotoxicity in renal tubular cells. Am. J. Physiol. Renal Physiol. 2008, 294, F577-F581. [CrossRef]

72. Liu, J.; Livingston, M.J.; Dong, G.; Tang, C.; Su, Y.; Wu, G.; Yin, X.M.; Dong, Z. Histone deacetylase inhibitors protect against cisplatin-induced acute kidney injury by activating autophagy in proximal tubular cells. Cell Death Dis. 2018, 9, 322. [CrossRef]

73. Jung, Y.J.; Lee, J.E.; Lee, A.S.; Kang, K.P.; Lee, S.; Park, S.K.; Lee, S.Y.; Han, M.K.; Kim, D.H.; Kim, W. SIRT1 overexpression decreases cisplatin-induced acetylation of NF-kappaB p65 subunit and cytotoxicity in renal proximal tubule cells. Biochem. Biophys. Res. Commun. 2012, 419, 206-210. [CrossRef]

74. Kim, D.H.; Jung, Y.J.; Lee, J.E.; Lee, A.S.; Kang, K.P.; Lee, S.; Park, S.K.; Han, M.K.; Lee, S.Y.; Ramkumar, K.M.; et al. SIRT1 activation by resveratrol ameliorates cisplatin-induced renal injury through deacetylation of p53. Am. J. Physiol. Renal Physiol. 2011, 301, F427-F435. [CrossRef]

75. Kim, J.Y.; Jo, J.; Kim, K.; An, H.J.; Gwon, M.G.; Gu, H.; Kim, H.J.; Yang, A.Y.; Kim, S.W.; Jeon, E.J.; et al. Pharmacological Activation of Sirt1 Ameliorates Cisplatin-Induced Acute Kidney Injury by Suppressing Apoptosis, Oxidative Stress, and Inflammation in Mice. Antioxidants 2019, 8, 322. [CrossRef]

76. Jung, Y.J.; Park, W.; Kang, K.P.; Kim, W. SIRT2 is involved in cisplatin-induced acute kidney injury through regulation of mitogen-activated protein kinase phosphatase-1. Nephrol. Dial. Transplant. 2020, 35, 1145-1156. [CrossRef]

77. Yoon, S.P.; Kim, J. Poly(ADP-ribose) polymerase 1 contributes to oxidative stress through downregulation of sirtuin 3 during cisplatin nephrotoxicity. Anat. Cell Biol. 2016, 49, 165-176. [CrossRef] [PubMed]

78. Kim, D.; Park, W.; Lee, S.; Kim, W.; Park, S.K.; Kang, K.P. Absence of Sirt3 aggravates cisplatin nephrotoxicity via enhanced renal tubular apoptosis and inflammation. Mol. Med. Rep. 2018, 18, 3665-3672. [CrossRef]

79. Chiba, T.; Peasley, K.D.; Cargill, K.R.; Maringer, K.V.; Bharathi, S.S.; Mukherjee, E.; Zhang, Y.; Holtz, A.; Basisty, N.; Yagobian, S.D.; et al. Sirtuin 5 Regulates Proximal Tubule Fatty Acid Oxidation to Protect against AKI. J. Am. Soc. Nephrol. 2019, 30, 2384-2398. [CrossRef] [PubMed]

80. Bertrand-Lehouillier, V.; Legault, L.-M.; McGraw, S. Endocrine Epigenetics, Epigenetic Profiling and Biomarker Identification. In Encyclopedia of Endocrine Diseases; Huhtaniemi, I., Martini, L., Eds.; Academic Press: Cambridge, MA, USA, 2019 ; pp. 31-35. [CrossRef] 
81. Kozomara, A.; Birgaoanu, M.; Griffiths-Jones, S. miRBase: From microRNA sequences to function. Nucleic Acids Res. 2019, 47, D155-D162. [CrossRef] [PubMed]

82. Pavkovic, M.; Robinson-Cohen, C.; Chua, A.S.; Nicoara, O.; Cardenas-Gonzalez, M.; Bijol, V.; Ramachandran, K.; Hampson, L.; Pirmohamed, M.; Antoine, D.J.; et al. Detection of Drug-Induced Acute Kidney Injury in Humans Using Urinary KIM-1, miR-21, -200c, and -423. Toxicol. Sci. 2016, 152, 205-213. [CrossRef] [PubMed]

83. Sun, W.; Zhu, Q.; Yan, L.; Shao, F. Mesenchymal stem cells alleviate acute kidney injury via miR-107-mediated regulation of ribosomal protein S19. Ann. Transl. Med. 2019, 7, 765. [CrossRef]

84. Wu, J.; Li, D.D.; Li, J.Y.; Yin, Y.C.; Li, P.C.; Qiu, L.; Chen, L.M. Identification of microRNA-mRNA networks involved in cisplatin-induced renal tubular epithelial cells injury. Eur. J. Pharmacol. 2019, 851, 1-12. [CrossRef]

85. Hao, J.; Lou, Q.; Wei, Q.; Mei, S.; Li, L.; Wu, G.; Mi, Q.S.; Mei, C.; Dong, Z. MicroRNA-375 Is Induced in Cisplatin Nephrotoxicity to Repress Hepatocyte Nuclear Factor 1-beta. J. Biol. Chem. 2017, 292, 4571-4582. [CrossRef] [PubMed]

86. Khandia, R.; Dadar, M.; Munjal, A.; Dhama, K.; Karthik, K.; Tiwari, R.; Yatoo, M.I.; Iqbal, H.M.N.; Singh, K.P.; Joshi, S.K.; et al. A Comprehensive Review of Autophagy and Its Various Roles in Infectious, Non-Infectious, and Lifestyle Diseases: Current Knowledge and Prospects for Disease Prevention, Novel Drug Design, and Therapy. Cells 2019, 8, 674. [CrossRef]

87. Yang, C.; Kaushal, V.; Shah, S.V.; Kaushal, G.P. Autophagy is associated with apoptosis in cisplatin injury to renal tubular epithelial cells. Am. J. Physiol. Renal Physiol. 2008, 294, F777-F787. [CrossRef] [PubMed]

88. Takahashi, A.; Kimura, T.; Takabatake, Y.; Namba, T.; Kaimori, J.; Kitamura, H.; Matsui, I.; Niimura, F.; Matsusaka, T.; Fujita, N.; et al. Autophagy guards against cisplatin-induced acute kidney injury. Am. J. Pathol. 2012, 180, 517-525. [CrossRef] [PubMed]

89. Zhu, Y.; Yu, J.; Yin, L.; Zhou, Y.; Sun, Z.; Jia, H.; Tao, Y.; Liu, W.; Zhang, B.; Zhang, J.; et al. MicroRNA-146b, a Sensitive Indicator of Mesenchymal Stem Cell Repair of Acute Renal Injury. Stem Cells Transl. Med. 2016, 5, 1406-1415. [CrossRef]

90. El Magdoub, H.M.; Schaalan, M.F.; Rahmo, R.M.; Farag, D.B.; Khedr, L.H. Implications of miRNAs on TGF-beta/TAK1/mTOR pathway in mediating the renoprotective effects of pentoxifylline against cisplatin-induced nephrotoxicity in rats. Toxicol. Appl. Pharmacol. 2020, 404, 115184. [CrossRef]

91. Jung, C.H.; Ro, S.H.; Cao, J.; Otto, N.M.; Kim, D.H. mTOR regulation of autophagy. FEBS Lett. 2010, 584, 1287-1295. [CrossRef]

92. De Almeida, D.C.; Bassi, E.J.; Azevedo, H.; Anderson, L.; Origassa, C.S.; Cenedeze, M.A.; de Andrade-Oliveira, V.; Felizardo, R.J.; da Silva, R.C.; Hiyane, M.I.; et al. A Regulatory miRNA-mRNA Network Is Associated with Tissue Repair Induced by Mesenchymal Stromal Cells in Acute Kidney Injury. Front. Immunol. 2016, 7, 645. [CrossRef]

93. Liao, W.; Fu, Z.; Zou, Y.; Wen, D.; Ma, H.; Zhou, F.; Chen, Y.; Zhang, M.; Zhang, W. MicroRNA-140-5p attenuated oxidative stress in Cisplatin induced acute kidney injury by activating Nrf2/ARE pathway through a Keap1-independent mechanism. Exp. Cell Res. 2017, 360, 292-302. [CrossRef]

94. Loboda, A.; Damulewicz, M.; Pyza, E.; Jozkowicz, A.; Dulak, J. Role of Nrf2/HO-1 system in development, oxidative stress response and diseases: An evolutionarily conserved mechanism. Cell Mol. Life Sci. 2016, 73, 3221-3247. [CrossRef] [PubMed]

95. Lu, M.C.; Ji, J.A.; Jiang, Z.Y.; You, Q.D. The Keap1-Nrf2-ARE Pathway As a Potential Preventive and Therapeutic Target: An Update. Med. Res. Rev. 2016, 36, 924-963. [CrossRef]

96. Xu, Y.; Ma, H.; Shao, J.; Wu, J.; Zhou, L.; Zhang, Z.; Wang, Y.; Huang, Z.; Ren, J.; Liu, S.; et al. A Role for Tubular Necroptosis in Cisplatin-Induced AKI. J. Am. Soc. Nephrol. 2015, 26, 2647-2658. [CrossRef] [PubMed]

97. Najafov, A.; Chen, H.; Yuan, J. Necroptosis and Cancer. Trends Cancer 2017, 3, 294-301. [CrossRef]

98. Zhang, S.; Sun, H.; Kong, W.; Zhang, B. Functional role of microRNA-500a-3P-loaded liposomes in the treatment of cisplatininduced AKI. IET Nanobiotechnol. 2020, 14, 465-469. [CrossRef] [PubMed]

99. Jiang, L.; Liu, X.Q.; Ma, Q.; Yang, Q.; Gao, L.; Li, H.D.; Wang, J.N.; Wei, B.; Wen, J.; Li, J.; et al. hsa-miR-500a-3P alleviates kidney injury by targeting MLKL-mediated necroptosis in renal epithelial cells. FASEB J. 2019, 33, 3523-3535. [CrossRef]

100. Pellegrini, K.L.; Han, T.; Bijol, V.; Saikumar, J.; Craciun, F.L.; Chen, W.W.; Fuscoe, J.C.; Vaidya, V.S. MicroRNA-155 deficient mice experience heightened kidney toxicity when dosed with cisplatin. Toxicol. Sci. 2014, 141, 484-492. [CrossRef]

101. Zhou, X.; Jiang, K.; Luo, H.; Wu, C.; Yu, W.; Cheng, F. Novel lncRNA XLOC_032768 alleviates cisplatin-induced apoptosis and inflammatory response of renal tubular epithelial cells through TNF-alpha. Int. Immunopharmacol. 2020, 83, 106472. [CrossRef] [PubMed]

102. Li, J.; Fan, X.; Wang, Q.; Gong, Y.; Guo, L. Long Noncoding RNA PRNCR1 Reduces Renal Epithelial Cell Apoptosis in CisplatinInduced AKI by Regulating miR-182-5p/EZH1. Kidney Blood Press. Res. 2021, 46, 162-172. [CrossRef]

103. Zhang, Y.; Tang, P.M.; Niu, Y.; Garcia Cordoba, C.A.; Huang, X.R.; Yu, C.; Lan, H.Y. Long Non-coding RNA LRNA9884 Promotes Acute Kidney Injury via Regulating NF-kB-Mediated Transcriptional Activation of MIF. Front. Physiol. 2020, 11, 590027. [CrossRef] [PubMed]

104. Zhang, M.; Bi, H.; Wang, S.; Sun, X.; Li, Y. Long non-coding RNA GAS5 aggravate renal epithelial cell apoptosis in cisplatininduced AKI by regulating miR-205-5p. Res. Sq. 2021. [CrossRef]

105. Huang, S.; Yang, B.; Chen, B.J.; Bliim, N.; Ueberham, U.; Arendt, T.; Janitz, M. The emerging role of circular RNAs in transcriptome regulation. Genomics 2017, 109, 401-407. [CrossRef] [PubMed]

106. Pellegrini, K.L.; Gerlach, C.V.; Craciun, F.L.; Ramachandran, K.; Bijol, V.; Kissick, H.T.; Vaidya, V.S. Application of small RNA sequencing to identify microRNAs in acute kidney injury and fibrosis. Toxicol. Appl. Pharmacol. 2016, 312, 42-52. [CrossRef] [PubMed] 
107. Wu, Z.; Li, C.; Li, Q.; Li, J.; Lu, X. Puerarin alleviates cisplatin-induced acute renal damage and upregulates microRNA-31-related signaling. Exp. Ther. Med. 2020, 20, 3122-3129. [CrossRef]

108. Joo, M.S.; Lee, C.G.; Koo, J.H.; Kim, S.G. miR-125b transcriptionally increased by Nrf2 inhibits AhR repressor, which protects kidney from cisplatin-induced injury. Cell Death Dis. 2013, 4, e899. [CrossRef] [PubMed]

109. Zhang, H.; Zhang, X.; Yuan, X.; Wang, L.; Xiao, Y. MicroRNA-205 inhibits renal cells apoptosis via targeting CMTM4. Iran. J. Basic Med. Sci. 2015, 18, 1020-1026. [PubMed]

110. Quintanilha, J.; Cursino, M.; Borges, J.; Torso, N.; Bastos, L.; Oliveira, J.; Cobaxo, T.; Pincinato, E.; Hirata, M.; Geraldo, M.; et al. MiR-3168, miR-6125, and miR-4718 as Potential Predictors of Cisplatin-Induced Nephrotoxicity in Patients with Head and Neck Cancer. Res. Sq. 2021. [CrossRef]

111. Pavkovic, M.; Riefke, B.; Ellinger-Ziegelbauer, H. Urinary microRNA profiling for identification of biomarkers after cisplatininduced kidney injury. Toxicology 2014, 324, 147-157. [CrossRef]

112. Wolenski, F.S.; Shah, P.; Sano, T.; Shinozawa, T.; Bernard, H.; Gallacher, M.J.; Wyllie, S.D.; Varrone, G.; Cicia, L.A.; Carsillo, M.E.; et al. Identification of microRNA biomarker candidates in urine and plasma from rats with kidney or liver damage. J. Appl. Toxicol. 2017, 37, 278-286. [CrossRef] [PubMed]

113. Glineur, S.F.; Hanon, E.; Dremier, S.; Snelling, S.; Berteau, C.; De Ron, P.; Nogueira da Costa, A. Assessment of a Urinary Kidney MicroRNA Panel as Potential Nephron Segment-Specific Biomarkers of Subacute Renal Toxicity in Preclinical Rat Models. Toxicol. Sci. 2018, 166, 409-419. [CrossRef]

114. Kanki, M.; Moriguchi, A.; Sasaki, D.; Mitori, H.; Yamada, A.; Unami, A.; Miyamae, Y. Identification of urinary miRNA biomarkers for detecting cisplatin-induced proximal tubular injury in rats. Toxicology 2014, 324, 158-168. [CrossRef]

115. Kagawa, T.; Zarybnicky, T.; Omi, T.; Shirai, Y.; Toyokuni, S.; Oda, S.; Yokoi, T. A scrutiny of circulating microRNA biomarkers for drug-induced tubular and glomerular injury in rats. Toxicology 2019, 415, 26-36. [CrossRef]

116. Zhang, W.; Chen, C.; Jing, R.; Liu, T.; Liu, B. Remote Ischemic Preconditioning Protects Cisplatin-Induced Acute Kidney Injury through the PTEN/AKT Signaling Pathway. Oxid. Med. Cell Longev. 2019, 2019, 7629396. [CrossRef]

117. Cho, Y.E.; Kim, S.H.; Lee, B.H.; Baek, M.C. Circulating Plasma and Exosomal microRNAs as Indicators of Drug-Induced Organ Injury in Rodent Models. Biomol. Ther. 2017, 25, 367-373. [CrossRef]

118. Huang, S.J.; Huang, J.; Yan, Y.B.; Qiu, J.; Tan, R.Q.; Liu, Y.; Tian, Q.; Guan, L.; Niu, S.S.; Zhang, Y.; et al. The renoprotective effect of curcumin against cisplatin-induced acute kidney injury in mice: Involvement of miR-181a/PTEN axis. Ren. Fail. 2020, 42, 350-357. [CrossRef] 